\title{
Indo-European nominal inflection in Nostratic perspective*
}

\begin{abstract}
The paper summarizes some of the current views on the history and origins of IndoEuropean nominal declension, including a brief comparison of several hypotheses on the mechanism of arisal of the "thematic" type of declension (o-stems). The reconstructed paradigmatic system is subsequently compared with the respective systems for other language families that form part of the hypothetical Nostratic macrofamily: Semitic (and Afro-Asiatic in general), Kartvelian, Uralic. It is concluded that, since most of the case endings of ProtoIndo-European are explainable either through internal derivation within Indo-European itself or through comparison with other Nostratic languages, the situation points strongly towards an analytic nature of Proto-Nostratic.
\end{abstract}

Keywords: Historical linguistics, Indo-European languages, comparative morphology, Nostratic hypothesis.

0. One of the parameters employed in the so-called typological classification of languages is whether the languages in question use or do not use affixation, i. e. whether they express such nominal grammatical categories as case, number, gender, grade, etc., or such verbal categories as person, number, time, aspect, mood etc., by means of suffixes, prefixes, or infixes. Such languages are called synthetic. Languages without affixation, called analytic, use other grammatical tools to express these categories (if they are differentiated in the first place), such as (frequently) various auxiliaries and particles, as well as more or less firmly fixed word order. Synthetic languages are further divided into agglutinative and flective. A basic feature of the agglutinative languages is that each of their affixes bears only one function (cf. e.g. Čermák 1997: 178-80). This can be illustrated on the example of three specimen agglutinative languages, Turkish, Finnish, and Georgian, where it is easy to identify the case endings that are universal for both singular and plural numbers: Table 1. In addition, Turkish and Georgian use only one plural suffix. In Finnish, two plural markers are differentiated: $-t$ in the nom.-acc. and $-i-/-j$ - in oblique cases.

0.1. From the "European" point of view, languages that classify nouns into specific semantic fields via so-called class affixes may seem exotic. Class affixes are congruentially introduced in adjectives, pronouns, numerals and verbs (sometimes they are lacking in nouns as such, with the exception of kinship terms in Nakh languages or kinship and anatomical terms in Burushaski from Hindukush, where they are productive). Vladimír Skalička (1945[2004]: 284-315) demonstrated that Swahili and other Bantu languages with class systems are flective inasmuch as several functions (e.g., class and number) may be cumulatively expressed with just one prefix. The same may be said about Bats, Chechen, and other languages with class prefixes spoken in the Northeastern Caucasus. On the other hand, the system of class prefixes in Aka-Bea on the South Andaman Island in the Indian Ocean bears apparent features of the agglutinative pattern: all plural prefixes are formed from the singular prefix by means of the universal plural morpheme -at-. It should be mentioned that Bats, Chechen, and Aka-Bea have their own case systems of agglutinative structure: Table 2.

* The present study was prepared thanks to the grant of the The Czech Science Foundation, P406/12/0655. 
Table 1.

\begin{tabular}{|c|c|c|c|c|c|c|c|c|}
\hline \multicolumn{3}{|c|}{ Turkish "house" } & \multicolumn{3}{|c|}{ Finnish "house" } & \multicolumn{3}{|c|}{ Georgian “son” } \\
\hline case & sg. & pl. & case & sg. & pl. & case & sg. & pl. \\
\hline nom. & $e v$ & ev-ler & nom. & talo & talo-t & nom. & švil-i & švil-eb-i \\
\hline acc. & $e v-i$ & $e v-l e r-i$ & acc. & talo & talo- $t$ & erg. & švil-ma & švil-eb-ma \\
\hline gen. & $e v-i n$ & ev-ler-in & gen. & talo- $n$ & talo-j-en & gen. & švil-is & švil-eb-is \\
\hline dat. & $e v-e$ & ev-ler-e & allat. & talo-lle & talo-i-lle & dat. & švil-s $(a)$ & švil-eb-s(a) \\
\hline loc. & $e v-d e$ & ev-ler-de & ines. & talo-ssa & talo-i-ssa & dir. & švil-ad(a) & švil-eb-ad(a) \\
\hline \multirow[t]{10}{*}{ abl. } & $e v-d e n$ & ev-ler-den & abl. & talo-lta & talo-i-lta & voc. & švil-o & švil-eb-o \\
\hline & & & instr. & talo- $n$ & talo-i-n & instr. & švil-it(a) & švil-eb-it(a) \\
\hline & & & part. & talo- $a$ & talo- $j-a$ & & & \\
\hline & & & es. & talo-na & talo-i-na & & & \\
\hline & & & trans. & talo-ksi & talo-i-ksi & & & \\
\hline & & & elat. & talo-sta & talo-i-sta & & & \\
\hline & & & ill. & talo-on & talo-i-hin & & & \\
\hline & & & ades. & talo-lla & talo-i-lla & & & \\
\hline & & & abes. & talo-tta & talo-i-tta & & & \\
\hline & & & comit. & - & talo-i-neen & & & \\
\hline
\end{tabular}

Abbreviations: abes. - abessive, abl. - ablative, adess. - adessive, acc. - accusative, all. - allative, comit. comitative, dat. - dative, elat. - elative, erg. - ergative, es. - essive, gen. - genitive, ill. - illative, instr. - instrumental, loc. - locative, nom. - nominative, part. - partitive, pl. - plural, sg. - singular, trans. - translative.

Table 2.

\begin{tabular}{|c|c|c|c|c|c|c|c|c|}
\hline \multicolumn{3}{|c|}{ Swahili (East Africa) } & \multicolumn{3}{|c|}{ Bats / Chechen (Northeast Caucasus) } & \multicolumn{3}{|c|}{ Aka-Bea (Andaman Islands) } \\
\hline class & sg. & pl. & class & sg. & pl. & class & sg. & pl. \\
\hline I. & $m u-/ m w-$ & $w a-$ & I. & $v-/ v u_{-}$ & $b-/ d u-$ & I. & $a b-$ & at- \\
\hline II. & $m u-$ & $m i ́-$ & II. & $j-/ j u-$ & $d-/ d u-$ & II. & ar- & arat- \\
\hline III. & $l i-\sim j i-$ & $m a-$ & III. & $j-/ j u-$ & $j-/ j u-$ & III. & $a k a-$ & akat- \\
\hline IV. & ki-/ch- & $v i-$ & IV. & $b-/ b u-$ & $b-/ b u-$ & IV. & $i g-/ i-$ & i-/iti- \\
\hline V. & $n-/ n y-10-$ & $n-/ n y-/ 0-$ & V. & $d-/ d u-$ & $d-/ d u-$ & $\mathrm{V}$. & ong- & oiot- \\
\hline VI. & $u-/ w-$ & $n-/ m a-/ \emptyset-$ & VI. & $b-/ b u-$ & $d-/ d u-$ & VI. & ot- & otot- \\
\hline VII. & $k u-$ & & VII. & $b-/-$ & $j-/-$ & & & \\
\hline VIII. & $p a-$ & & VIII. & $d-/-$ & $j-/-$ & & & \\
\hline IX. & $k u^{-}$ & & & & & & & \\
\hline$X$. & $m u-$ & & & & & & & \\
\hline
\end{tabular}

Functions of the class prefixes:

Swahili: I. human beings; II. trees \& plants, tools \& products, some body parts, abstracts; III. paired body organs, fruits, liquids, big things, foreign words; IV. things; V. animals; VI. abstracts \& extracts, names of countries; VII. verbal infinitives; VIII. locatives; IX. locatives; X. locatives.

Bats: I. male beings; II. female beings; III.-VIII. animals, inanimate nature, things, abstracts.

Aka Bea: I. body, back, thighs, lap, shins, calves, groin, elbows, arms, knees, ribs, navel, belly etc.; II. legs, hip, kidney, anus, urine, urinary bladder, peritoneum, gut, scrotum, buttocks; III. mouth, palate, chin, lips, tongue, throat, 
pharynx, trachea, jaw, vertebra, saliva, breathe etc.; IV. eyes, eyebrow, eyelids, gum, face, forehead, ears, nose, cheeks, temples, teeth, shoulders, forearm, biceps, breasts, nipples, tears; V. hands, fingers \& toes, fingernails, sole of the foot, heels, joints, spleen, small intestine; VI. heart, head, neck, chest, brain, nape, lungs, phlegm.

0.2. Indo-European languages have been cited as a typical example of flective languages. This supposes the presence of more or less stable word roots which are extended by derivational affixes and grammatical morphemes. These may bear several functions, e.g. Latin servī, formed from the nom. sg. servus "servant, slave", expresses both the gen. sg. m. and nom.-voc. pl. m., i.e. a single ending accumulates the grammatical meanings of case, number, and gender. As a sub-variant of the flective type, the introflective subtype has also been defined. This term refers to the so-called 'internal inflection', specified both on the affixes and the root of the word; as a rule, it is represented by vocalic alternations. As an illustrative example, we may cite the so-called 'broken' plurals of Semitic nouns, e.g. Classical Arabic rağulun "man", pl.

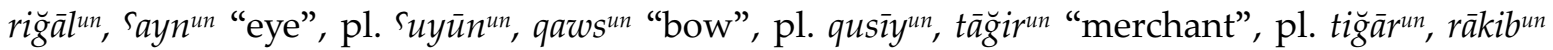
“rider", pl. rakbun Hebrew rōkệb, pl. rekeb, hịmārun "ass", pl. hamīìn (final -un in Arabic represents the so-called nunation that performs the function of a determinant and is neither a part of the root nor of the stem). In Indo-European nominal paradigms such vocalic alternations, which can be classified as internal inflection, appear too, and are usually specified as 'ablaut' or 'apophony'. Thus, in the paradigm of the word "water" different variants of the root are present in the nom. sg. "uód-r, loc. sg. *ud-én, nom.-acc. col. " uéd-ōr (NIL: 706-07); the basic paradigm of the word "winter" is also reconstructed at least in three apophonic variants: nom. ${ }^{*} \hat{g}^{h}$ éiom, acc. ${ }^{*} \hat{g}^{h}{ }^{h}$ iém-mo, gen. ${ }^{*} \hat{g}^{h} i m$-ós (Beekes 1995: 178). Even more important is the role of the ablaut in the Indo-European verb.

Naturally, it is very rare for any language to be in complete agreement with the criteria that define concrete language types in the typological classification of Skalička. A more adequate statement is that in any one language one type is usually dominant, but other types may also appear, although they may be rudimentary or, vice versa, in statu nascendi.

1. Proto-Indo-European is generally seen as having had the same nominal word classes that are present in historically attested Indo-European languages, i.e. nouns, adjectives, pronouns, numerals. Numerals were declined the same way as nouns and adjectives, although this rule originally covered only numerals from 1 to 4 ; higher order numerals were indeclinable, just like adverbs, conjunctions, and particles. Pronouns had their own inflection system, frequently different from nominal inflection; both types of inflection could also influence one another. Nouns and adjectives (the latter serving as congruent attributes to governing nouns) differentiated three basic grammatical categories: number, case and gender. There were three numbers - singular, plural and dual, although the dual has not been preserved in all the branches. Traditionally, a system of 8 cases has been reconstructed, based on the situation in Vedic and Avestan. However, more modest case inventories in Greek, Celtic, Germanic, and especially in Anatolian imply the question whether a paradigm with fewer cases could reflect the original situation. The same issue is seen with grammatical gender: Brugmannian reconstruction operated with three genders (masculine, feminine and neuter), but the Anatolian languages differentiated only two genders. This discrepancy may be solved by the assumption of two chronological phases. In the early phase, only two genders would be differentiated, expressing the opposition "active : inactive", whereas in the later phase, after the separation of the Anatolian branch, the traditional tripartite gender system would be introduced (Vavroušek 2008: 59). An alternative model assumes an original feminine gender and its elimination in the Anatolian branch (cf. Beekes 1995: 174). 
1.1. From the point of view of word formation, an Indo-European noun consists of the root (sometimes extended with a derivational suffix) + stem-forming suffix + case ending. A good example may be the word ${ }^{*} \mathrm{H}_{2} \mathrm{erH}_{3}$-tr-o-m "plough", reconstructed on the basis of Arm. arawr, Gr. ä@ot@ov, Lat. aratrum, MIr. arathar, Welsh aradr, ON. arðr. It consists of the verbal root ${ }^{*} \mathrm{H}_{2} \mathrm{erH}_{3^{-}}$"to plough", the derivational suffix *-tr-, the stem-forming marker -o- classifying the word as a so-called $o$-stem, and the ending $-m$ of the nom.-acc. sg. of the neuter gender. Out of all these segments, it is only the stem-forming suffix that determines the inflectional class to which the noun in question belongs. A basic division has been sought between socalled vocalic and consonantal stems. The $o$-stems and $\bar{a}$-stems are traditionally understood as vocalic, whereas the so-called $i$-stems and $u$-stems belong to the consonantal type, being resonants. If the $-\bar{a}$ of the $\bar{a}$-stems is reinterpreted in agreement with the laryngeal theory as * $e H_{2}$, the result will also be a consonantal coda; likewise, in the case of $\bar{\imath}$ - and $\bar{u}$-stems, which, in their laryngealistic reinterpretation, are really $i H$ - and $u H$-stems. In other words, the vocalic stems will be represented only by the $o$-stems, while all the other ones will (at least historically) be consonantal stems. In nominal paradigms with ablaut the cases are called strong if the stem has the full ablaut grade, and weak if the stem has the zero ablaut grade. The full ablaut grade generally appears in nom., acc., voc. sg. and pl. and usually in the loc. sg. (Szemerényi 1996: 161).

1.2. When reconstructing Indo-European nominal inflection, syllabic accent should also be taken in account. This phenomenon, neglected by Neogrammarians, was given a new interpretation by Holger Pedersen (1926: 24), who himself came from the Neogrammarian milieu. For the consonantal stems he defined two types of inflection according to differences of ac-

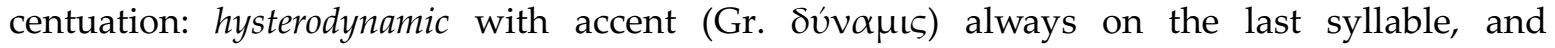
proterodynamic with accent moving between the first syllable and the stem-forming suffix.

In the 1970s his ideas were further developed by Karl Hoffmann, a representative of the so-called Erlangen School. Hoffmann defined 5 types of inflection depending on the position

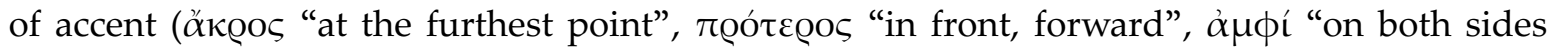

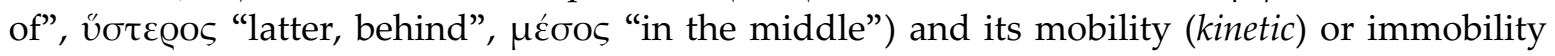
(static): (1) akrostatic - accent always remains on the root; (2) proterokinetic - accent stays on the root in strong cases, shifts to the stem-forming suffix in weak cases; (3) hysterokinetic - accent always remains on the final syllable, which alternately coincides with the stem-forming suffix in strong cases and the case ending in weak cases; (4) amphikinetic - accent moves from the root in strong cases to the case ending in weak cases; (5) mezostatic - accent remains on the stem-forming suffix; if this suffix is preceded by another derivational suffix, accent shifts position between them (Szemerényi 1996: 161-62).

2. The so-called thematic inflection is limited only to nouns extended by the vowel -o(which shifts to -e- in the voc. sg.), the so-called $o$-stems. Unless indicated otherwise, in table

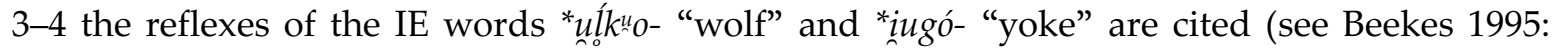
190-92; GHL: 79-83; Fortson 2004: 113-16; Szemerényi 1996: 182-88).

Apart from the singular (Table 3) and plural (Table 4), Proto-Indo-European also had a separate dual category (Tables 5-7), although it was not preserved in all daughter branches. Thus, in old literary Germanic languages the dual disappeared from the nominal morphology but remained in the pronominal and verbal systems. In Latin traces of the dual are preserved

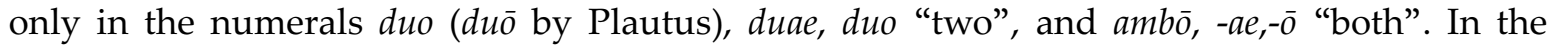
Anatolian branch the traces of dual have been sought in designations of paired body parts, e.g. Hitt. sakuwa "eyes", Luw. aruta "wings", issara "hands", pata "feet" (Krasuxin 2004: 133; Szemerényi 1996: 161). Because of homonymy of endings, the dual paradigm is less rich in comparison with plural even in those languages where the dual number was preserved. 
Table 3.

\begin{tabular}{|c|c|c|c|c|c|c|c|c|c|}
\hline sing. & Vedic & Hittite & Greek & Latin & OIrish & Gothic & Lith. & OCS. & IE \\
\hline nom. & vŕkas & $\begin{array}{l}\text { ishăs } \\
\text { "lord" }\end{array}$ & $\lambda u ́ \kappa о \varsigma^{6}$ & lupus $^{14}$ & $\mathrm{fer}^{24}$ & wulfs $s^{34}$ & vil̃kas & vlokb & ${ }^{*}$-OS \\
\hline vok. & $v{ }_{0} k a^{1}$ & $i s h \breve{a}$ & $\lambda u ́ \kappa \varepsilon$ & lupe 15 & fir $^{25}$ & wulf & vilke & vloče & $*-e$ \\
\hline acc. & vớkam & ishān & $\lambda u ́ \kappa O v^{7}$ & lupum $^{16}$ & $\mathrm{fer}^{26}$ & wulf $^{35}$ & vilikaqu & $v l b k b$ & ${ }^{*}$-om \\
\hline $\begin{array}{l}\text { nom.- } \\
\text { acc. n. }\end{array}$ & yugám & yugan & $\zeta u \gamma o ́ v^{8}$ & iugum ${ }^{17}$ & scél 27 & $\begin{array}{l}\text { juk; } \\
\text { ORun. } \\
\text { horna } \\
\text { "horn" }\end{array}$ & $\begin{array}{l}\text { Pr. } \\
\text { lunkan }^{41}\end{array}$ & igo & ${ }^{*}$-om \\
\hline gen. & vrókasya & $i s h \bar{a} s^{4}$ & $\lambda u^{\prime} \operatorname{coto}^{9}$ & $\begin{array}{l}\text {-osio }{ }^{18} \\
\operatorname{lup}^{19}\end{array}$ & $\begin{array}{l}\text { ?-oiso }{ }^{28} \\
\text { fir }^{29}\end{array}$ & $\begin{array}{l}\text { ORun. } \\
-a s^{36} \\
\text { wulfis }{ }^{37}\end{array}$ & $\begin{array}{l}\text { Pr. }-a s^{42} \\
=a b l\end{array}$ & $=\mathrm{abl}$. & $\begin{array}{l}{ }^{*} \text {-os } \\
{ }^{*} \text {-os-io } \\
{ }^{*}-i^{46}\end{array}$ \\
\hline abl. & vrókād & antuhset ${ }^{5}$ & $\begin{array}{l}e-k o-m e- \\
n o^{10}\end{array}$ & $\operatorname{lup} \bar{o}^{20}$ & $\begin{array}{l}\mathrm{CIb} . \\
-u \partial^{30}\end{array}$ & & vilk $k o^{43}$ & vlok $k a^{42}$ & $\begin{array}{l}{ }^{*}-\bar{o} d \\
<{ }^{*}-o-e d^{47}\end{array}$ \\
\hline dat. & vrók $k \bar{a} y a^{2}$ & $i s h \bar{\imath}$ & $\lambda u ́ \kappa \omega t^{11}$ & lupo $\bar{o}^{21}$ & fiur $^{31}$ & $\begin{array}{l}\text { ORun. } \\
-a i^{38}\end{array}$ & vil̃kui & vloku & $\begin{array}{l}{ }^{*}-\bar{o} i \\
<{ }^{*}-0-e i\end{array}$ \\
\hline loc. & vorke & $i \operatorname{sh} \bar{\imath}$ & OйKOІ ${ }^{12}$ & $\operatorname{dom} \vec{\imath}^{22}$ & CIb. $-e i^{32}$ & $\begin{array}{l}\text { dat. } \\
\text { wulfa }\end{array}$ & vilkè44 & vlbcě & $\begin{array}{l}{ }^{*}-O i \\
<{ }^{*}-O-i\end{array}$ \\
\hline inst. & v̛́k keṇa $a^{3}$ & & $\begin{array}{l}a \text {-to-ro- } \\
q o^{13}\end{array}$ & $\operatorname{lup} \bar{o}^{23}$ & CIb. $-u^{33}$ & $\begin{array}{l}\text { dat. } \\
\text { wulfa }{ }^{39}\end{array}$ & vilkù & vlrkomb ${ }^{45}$ & $\begin{array}{l}{ }^{*}-\mathrm{oH} \\
<{ }^{*}-\mathrm{o}-\mathrm{H}_{1}\end{array}$ \\
\hline
\end{tabular}

Notes: see Beekes 1995: 190-92; GHL 79-83; Szemerényi 1996: 182-88; 1) Absence of palatalization of the velar is explainable via paradigmatic levelling. 2) Final $-a$ is a particle (Beekes 1995: 192). 3) Adapted from the pronominal inflection, cf. the instr. sg. of demonstratives ena, téna, eténa, interrogative kéna, relative yéna, reflexive svéna (Macdonell 1916[2000]: 77, 106-12). 4) Corresponds to the gen. ending of other inflectional types. In the Luwian subbranch the genitive is replaced by so-called possessive adjectives, formed by the suffix -assi-in Cuneiform Luwian and -asi- in Hieroglyphic Luwian. Szemerényi (1996: 184, 187; following Mittelberger) derived them from the $o$ stem gen. in *-os-io. 5) Instr. sg. from antuhsas "man". Abl. sg. has the ending -az. 6) Cf. Myc. wo-no /woinos/ "vine". 7) Cf. Myc. to-ro-qo /trokwon/ "strap" or wo-i-ko-de, wo-ko-de/woikon-de/ "in the house". 8) Cf. Myc. e-ra-wo /elaiwon/ "olive oil". 9) Cf. Myc. do-e-ro-jo /do(h)elojjo/ "servant". 10) Myc. toponym, which may preserve the abl. sg. in /-o/.

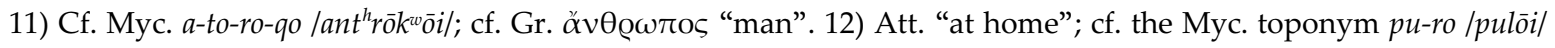
“in Pylos”. 13) Myc. /ant ${ }^{h} \bar{k}^{w} \bar{o} /$ (notes 6-13: see Bartoněk 2003: 188-210 \& Hajnal 1995: 23-24). 14) Cf. OLat. equos (Plautus), duenos (CIL I, 4), further Fal. Kaios, Ven. Voltiiomnos, Osc. húrz "grove", SPic. meitims "gift”?. 15) Cf. Fal. Uoltene, Umb. Šerfe, Osc. Fatofe. 16) Cf. OLat. manom "hand", Fal. vinom "vine", Ven. ekvon "horse", Osc. húrtúm, dolom “intent”, SPic. meitimúm. 17) Cf. OLat. donom "gift”, Fal. duenom "good”, Ven. donom \& donon "gift”, osk. sakaraklúm, vol. pihom “of pious”. 18) Cf. OLat. Popliosio Valesiosio = class. Lat. 'Publii Valerii' (Lapis Satricanus, 500 BC), Fal. Kaisiosio. 19) Cf. OLat. Aisclapi (CIL I, 440), argentī (Plautus) “of silver” (adj.), Fal. Marci, Ven. louki “of sacred grove". 20) Cf. OLat. fileod "to son", Osc. sakaraklúd "to sanctuary". 21) Cf. OLat. Numasioi duenoi, later Aiscolapio, Fal. Kaisioi, Ven. murtuvoi "to dead", Osc. húrtúi, SPic. brímeqlúi. 22) Lat. "in homeland”, lit. "at home”; cf. Osc. húrteí. 23) In a form such as lupō there was a merger of three cases - dative, ablative \& instrumental sg.; cf. also Ven. instr. Voltiio (notes 14-23: see Meiser 1998: 134-35; UB: 228-30). 24) Goid. *uiros “man”; cf. Clb. ueiðos “witness”, G1. tarvos "bull”, Lep. Alkouinos, Ulkos. 25) Goid. *uire, cf. Gl. (Lezoux) nate “oh, son!” (LG: 143). 26) Goid. *uirom; cf. CIb. elaðunom, Gl. (Alise) celicnon "hall”, but (Larzac) brictom "magic". 27) Olir. scél "message” < *sk"etlom (LEIA: S 39-40); cf. CIb. Belikiom, Lep. uinom "vine”, Gl. (Chamalières) ollon "all”, meíon "small”. 28) Lep. gen. sg. Xosioiso. Metathesis? 29) Goid. *uirī, Ogam maqqi “of son”; cf. Gl. (Couchey) Segomari, (Todi) Trutikni, Lep. Aśkoneti, but CIb. -o in karuo etc. 30) CIb. Usamuð. 31) Goid. *uirū; cf. CIb. ueiðui, Lep. Pelkui, Gl. (Cavaillon) $\beta \alpha \lambda \alpha v \delta o v ı$ \& (Couchey) Alisanu. 32) CIb. kortonei, Gl. -e: uo duno derce "under the barrow", in Alixie "in Alesia". 33) CIb. auku, Gl. sunartiu "by good strength" (notes 24-33: see Lejeune 1971: 467; LG: 51-56; MLH: 396-400).

34) Cf. ORun. laukaz "garlic". 35) Cf. ORun. staina "stone”. 36) ORun. Godagas. 37) Gmc. *-eso, adapted from the 
pronominal inflection, cf. Goth. wis "what”, pis "that”, OCS. česo "what”. 38) Cf. ORun. hahai. 39) Cf. the instr. sg. in OSas. dagu, OHG. tagu "by day". 40) Cf. Prus. deiwan "god". 41) Prus. "bast". 42) Prus. deiwas. 43) *-ād as in the $\bar{a}$-stems (cf. Szemerényi 1996: 183). 44) The diphthong remains fossilized in such adverbs as Lith. namie "at home", Prus. bitai "in the evening". 45) Levelled after other inflectional patterns (Erhart 1982: 120). The original ending, which should be * $a$, may have been fossilized in the interrogative \& relative OCS. adv. kogda, kbgda "when", if it is a compound of the pronominal root * $k o-$, ${ }^{*} k b$ - and the word godv "time" (Wiedmann apud Brugmann 1911: 189). 46) Cf. also Alb. et "of father" < *attī : nom. atë; Toch. A Mahiśvari "Mahiśvari's”, maybe also the genitive of kinship terms such as A pācri, B pätri "of father" (Klingenschmitt 1992: 98-104). 47) Only the abl. sg. of the $o$-stems differs from the gen. sg., in other inflectional classes gen. \& abl. sg. merge (with the exception of Italic, Celtiberian and Anatolian languages, where the dental ablative was extended in other inflectional classes). Its origin has been sought in the pronominal ablative of the type of Ved. mad, OLat. (also acc.) med (Praeneste), méd (Plautus), Fal. med, met, similarly OLat. ted \& sed, and perhaps Gl. * med \& *sed in the syntagms to-med-ec-lai (Voltino, North Italy), met-ingi-setingi "between me and between her" (Châteaubleau; see Lambert 2001: 112). The ending is identified with the particle ${ }^{*} a d<{ }^{*} H_{2} e d$ (Dunkel, Sihler etc.) or ${ }^{*}$ eti $\sim{ }^{*}$ oti $<{ }^{*} H_{1} e t i \sim{ }^{*} H_{1}$ oti (Neu, Tichy etc.), see Szemerényi 1996: 187).

Table 4.

\begin{tabular}{|c|c|c|c|c|c|c|c|c|c|}
\hline plur. & Vedic & Hittite & Greek & Latin & OIrish & Gothic & Lith. & OCS. & IE \\
\hline nom. & vrókās & ishēs & $\lambda u ́ \kappa o l^{3}$ & $\begin{array}{l}\text { O.-U. - } u s^{9} \\
\operatorname{lup} \bar{\imath}^{10}\end{array}$ & $f i r^{16}$ & wulfos ${ }^{24}$ & vilkaĩ $^{29}$ & vloci & $\begin{array}{l}{ }^{*}-\overline{O S} \\
<{ }^{*}-0-e s \\
{ }^{*}-o i\end{array}$ \\
\hline acc. & vớkāan ${ }^{1}$ & EN.MEŠ- $u s$ & 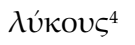 & lupōs ${ }^{11}$ & firu $^{17}$ & wulfans & vilkùs ${ }^{30}$ & vloky $y^{35}$ & *-oms \\
\hline $\begin{array}{l}\text { nom.- } \\
\text { acc. n. }\end{array}$ & yugá & & $\zeta v \gamma \alpha^{5}$ & $i u g a^{12}$ & $\begin{array}{l}\operatorname{scél}(a)^{18} \\
\text { CIb. }-a^{19}\end{array}$ & $j u k a^{25}$ & $\begin{array}{l}\text { Prus. } \\
\text { warto }^{31}\end{array}$ & $i g a$ & ${ }^{*}-(e) \mathrm{H}_{2}$ \\
\hline gen. & vớkānām ${ }^{2}$ & $\begin{array}{l}\text { siunan } \\
\text { "god" }\end{array}$ & $\lambda u ́ \kappa \omega v^{6}$ & $\begin{array}{l}\text { lupō- } \\
\text { rum }^{13}\end{array}$ & $f e r^{20}$ & $\begin{array}{l}-o /-a^{26} \\
\text { wulfe } e^{27}\end{array}$ & vilk $\tilde{u}^{32}$ & vlokb & $\begin{array}{l}\text { *-ŏ } m \\
<{ }^{*}-o-o m\end{array}$ \\
\hline $\begin{array}{l}\text { dat.- } \\
\text { abl. }\end{array}$ & vŕkebhyas & ishas & & $-o i b o s^{14}$ & $f e r(a) i b^{21}$ & wulfam $^{28}$ & vilkáms ${ }^{33}$ & vlokomb & $\begin{array}{l}*-o i-b^{h} / m- \\
{ }^{*}-o i-o s ?\end{array}$ \\
\hline loc. & vŕkeșu & ishas & $\lambda u ́ \kappa O \iota \sigma \iota^{7}$ & lupiss ${ }^{15}$ & $-e i^{22}$ & & vilkuosè ${ }^{34}$ & vlocěxb & ${ }^{*}-o i-s u$ \\
\hline inst. & vrókais & & $\lambda u ́ \kappa о \iota \varsigma^{8}$ & lupiss ${ }^{15}$ & $-u i s /-u s^{23}$ & & vilkaĩs & vlvky $y^{36}$ & *-吕i $i s^{37}$ \\
\hline
\end{tabular}

Notes: see Beekes 1995: 192; Fortson 2004, 113-16; Szemerényi 1996: 183-88; 1) Long -ā- levelled after the nom. pl. -ās. Better is preserved the acc. pl. in OAv. maṣ̌iiōng, maṣiiąs-cā "man” (*mortal”) < *martianh, "ans-ca; cf. Ved. márti yān, márt $i \bar{a}$ miśs $c a$ (Hoffmann \& Forssman 1996, 120). 2) Through influence of the $n$-stems. The primary gen. pl. is preserved e.g. in the syntagm dévāñ janma "race of gods" (Szemerényi 1996: 185). 3) Cf. Myc. o-no /onoi/ “don-

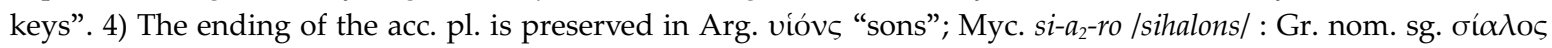

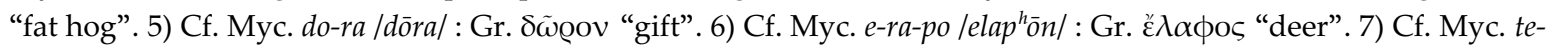

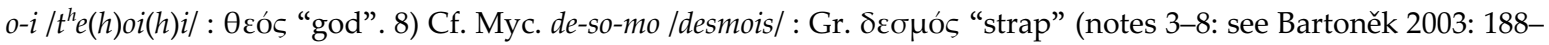
210; Hajnal 1995: 23-24). 9) Osc. Núvlanús, SPic. Safinús, Umb. Ikuvinu. 10) Cf. OLat. peploe, besides epigraphic Virei. 11) Cf. OLat. deivos, Ven. deivos, Osc. feíhúss, Umb. vitluf. 12) Cf. Umb. iuku \& iuka. 13) Adapted from the pronominal inflection: ${ }^{\circ} \overline{o r u m}<{ }^{*}-\bar{u}$ som $<{ }^{*}$-oi-s-š̄m, cf. the Vedic demonstrative téșām, OCS. těxz. The nominal gen. pl. is preserved in OLat. deom, Ven. Oterginon, Pael. Cerfum, CPic. Safinúm, Osc. Núvlanúm. 14) Ven. ekvoibos, besides louderobos. 15) In Lat. the dat.-abl. pl. of $o$-stems in -is merged with two other cases, the loc. pl. in *-oi-su, and instr. pl. in *-ois. The diphthong is also preserved in OLat. qurois, poplois, Pael. puclois, Osc. feíhúís, zicolois (notes 9-15: see

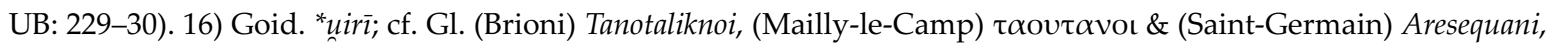
Lep. Kasiloi, CIb. Alaboi. The original nom. pl. in *-ōs was preserved in OIrish voc. pl. firu < Goid. *uirūs. 17) Goid.

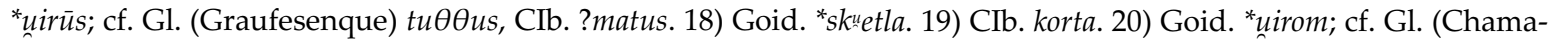
lière) diiiuion \& ande-dion, CIb. Titum. 21) Goid. *uiro[i]bi(s) (Thurneysen 1946: 182) with the ending *-bi(s), corresponding to the Gl. instr. pl. gobedbi, cf. dat. pl. in Gl. Rudiobo, Lep. Uvltiauobos, CIb. Uetikubos, similarly abl. pl. Nouantubos. 22) CIb. Lutiakei (Cólera 2005: 124). 23) Gl. (Vaison) toovtıos / (Graufesenque) Vindulus. 24) The pronominal nom. pl. in -ai appears in the Gothic strong adjective nom. pl. m. blindai "blind". Further cf. ORun. 
arbijarjostez "most legitimate-to-inherit"?, besides later stAinAz “stones", ON. ulfar "wolves". 25) Cf. ORun. hagalu

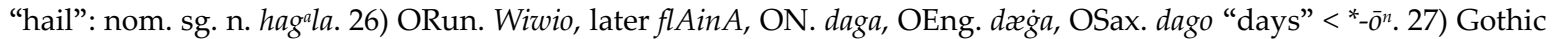
gen. pl. m./n. in $-e$ instead of expected ${ }^{+}-o$ had perhaps to eliminate homonymy with the gen. pl. f. (Brugmann 1911: 238-39; Ringe 2006: 282). Kortlandt apud Beekes (1985: 142) explains -e from Gmc. *-e < *-ei-om, thus from the gen. pl. $i$-stems, whence the ending had to spread. 28) Cf. ORun. borumz "to sons". Kortlandt (apud Beekes 1985: 144) explains the vowel $u$ in the OHG. dat. pl. tagum via $u$-umlaut caused by vocalization of the ending *-mus (notes 23-27: see Antonsen 1975: 18-19). 29) Cf. Prus. wijrai "men”. 30) Lith. -us < *uos < *ōns (Otrębski III: 16). Cf. Prus. deiwans “gods”. 31) Prus. “doors”. 32) Cf. Prus. grīkan : nom. sg. grīkas “sin”. 33) Cf. OLith. [Daukša's Postilla] waykâmus = Lith. vaikáms "to children". 34) The Lith. ending of loc. pl. could be the result of contamination with acc. pl. *-uons and postposition *-en, cf. Žemaitic loc. pl. in -unse (Otrębski III: 16). 35) Sl. acc. pl. -y<*-ōns. 36) Sl. instr. pl. -y<*-ois (Erhart 1982: 121). 37) Instr. pl. in *-ois (Gr., It., Balt.) or *-ois (II., Celt., Sl.) remains obscure. Maybe it is the instr. sg. in *-oH$H_{1}$ extended with non-singular *-oi- and pluralizing -s (otherwise Erhart 1982: 98; Szemerényi 1985: 519-20).

Table 5.

\begin{tabular}{|c|c|c|c|c|c|c|c|}
\hline dual. & Vedic & Avestan & Greek & Old Irish & Lith. & OCS. & IE \\
\hline $\begin{array}{l}\text { nom.-acc. } \\
\text { m.f. }\end{array}$ & vrókā, vrókau & $s p \bar{a} d \bar{a}^{3}$ & $\lambda u ́ \kappa \omega^{7}$ & fer $<$ *uirā & vilkù & vloka & ${ }^{*}-o-H_{1}$ \\
\hline nom.-acc. n. & yugé & šiiao $\theta n o \bar{i} i^{4}$ & $\zeta v \gamma \omega^{8}$ & scél ${ }^{11}$ & & $i(d) z \check{e}$ & ${ }^{*}-o-i H_{1}$ \\
\hline gen. & $=$ loc. & aqsaiii $\bar{a}^{5}$ & $=$ loc. & fer $<$ *uirou & dvíejaus $^{12}$ & $=$ loc. & ${ }^{*}-o i-H_{1} \bar{o} s$ \\
\hline loc. & vớkayos ${ }^{1}$ & ${\text { zastaii } \bar{o}^{6}}$ & 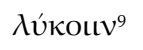 & & dvíejau ${ }^{12}$ & vlvku & ${ }^{*}-\mathrm{oi}-\mathrm{H}_{1} \mathrm{Ou}$ \\
\hline $\begin{array}{l}\text { dat.-abl.- } \\
\text { inst. }\end{array}$ & $\begin{array}{l}\text { vớkābhyām } \\
\text { aśvebhyām }{ }^{2}\end{array}$ & $\begin{array}{l}\text { zastōibiiāa } \\
\text { aspaēbii }^{2}\end{array}$ & & $\begin{array}{l}\text { fer }(a) i b \\
<* \text { uirobim }\end{array}$ & vilkám & vlokoma & $\begin{array}{l}{ }^{*}-o i-b^{h} \underset{j o H_{1}}{ } \\
{ }^{*}-o-m o H_{1}\end{array}$ \\
\hline instr. & & & $o-m o-p i^{10}$ & & vilkañ & & ${ }^{*}-o-b^{h} / m i H_{1}$ \\
\hline
\end{tabular}

Notes: see Beekes 1995: 194-95; Brugmann 1911: 282-83; Hoffmann \& Forssman 1996; Szemerényi $1996: 183-85$. 1) *-oi- $\mathrm{H}_{1} \mathrm{ou}+-\mathrm{s}$, perhaps levelled after the gen. 2) "horse". 3) OAv. spāda- "army". 4) OAv. šiiaoOna- "action", cf. YAv. saite "200", duiie, duuaē-ca "2". 5) OAv. assa- "share". 6) OAv. zasta- "hand". 7) Cf. Myc. po-ro /pōlō/ "two foals". 8) Ending of the m.-f. du. 9) Rix (1976: 141): *-oisin after the dat.-loc. pl. *-oisi with final nasal after the instr. du. *-oi$b^{h}$ im; otherwise Beekes (1995: 195): *-oi-Hu-m? 10) Myc. /oimophi/ : Gr. oĩuos "bundle” (Hajnal 1995: 23). 11) Causes nasalization of the following initial: maybe due to contamination with the ending of nom. sg. n. *-om. More original is perhaps Gl. uercobreto (Thurneysen 1946: 182). 12) Lith. dveji “double”.

Table 6.

\begin{tabular}{|c|c|c|c|c|c|c|c|}
\hline$e \mathrm{H}_{2}$-stems & Vedic & Avestan & Greek & OIrish & Lithuanian & OCS. & IE \\
\hline nom.-acc. & $\begin{array}{l}\text { séne } \\
\text { "army” }\end{array}$ & uruuaire $^{1}$ & $\theta \varepsilon \overline{\bar{\alpha}}^{3}$ & túaith ${ }^{5}$ & $\begin{array}{l}\text { rankì } \\
\text { "hands" }\end{array}$ & $\begin{array}{l}\text { rocě } \\
\text { "hands" }\end{array}$ & ${ }^{*}-e H_{2}-i H_{1}$ \\
\hline gen.-loc. & sénayos & uruuaraiiōa & $\theta \varepsilon \alpha \tilde{\mathrm{I}} \mathrm{v}^{4}$ & túath & & roku & $\begin{array}{l}{ }_{-}^{*} e \mathrm{H}_{2}-i \mathrm{H}_{1}- \\
\mathrm{H}_{1} \mathrm{ou}\end{array}$ \\
\hline $\begin{array}{l}\text { dat.-abl.- } \\
\text { ins. }\end{array}$ & sénābhyām & $v a ̨ \theta \beta \bar{a} b i i a^{2}$ & & túath $(a) i b^{7}$ & rañkom & rokama & $\begin{array}{l}*-e H_{2}-b i o H_{1} \\
*-e H_{2}-m o H_{1}\end{array}$ \\
\hline
\end{tabular}

Notes: see Beekes 1995: 194-95; Brugmann 1911: 284-85; Hoffmann \& Forssman 1996: 122; Krasuxin 2004: 140;

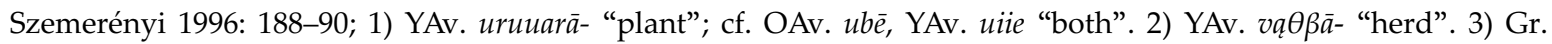

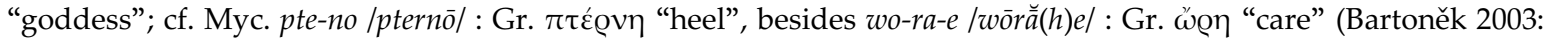
618; Hajnal 1995: 16). Final -a-e may reflect *-a( $(i) e<{ }^{*}-e H_{2}-i H_{1}$ (Rix 1976: 135). 4) Cf. Myc. wa-na-so-i /wanasso(j)i(n)/:

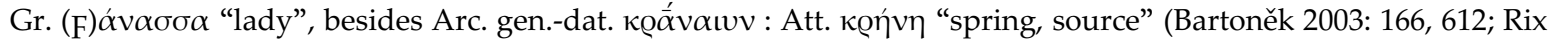

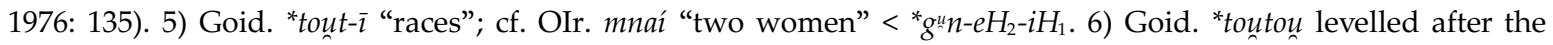
o-stems. 7) Goid. *tountābim (Thurneysen 1946: 189-90). 
Table 7.

\begin{tabular}{|c|c|c|c|c|c|c|c|}
\hline cons. stems & Vedic & YAvestan & Greek & OIrish & Lith. & OCS. & IE \\
\hline $\begin{array}{l}\text { nom.-acc. } \\
\text { m.f. }\end{array}$ & pitárā,-au ${ }^{1}$ & nara $^{3}$ & $\pi \alpha \tau \varepsilon^{2} \mathrm{Q} \varepsilon^{4}$ & athir & žmune ${ }^{11}$ & kameni $^{14}$ & ${ }^{*}-H_{1} e$ \\
\hline nom.-acc. n. & ná́manī ${ }^{2}$ & & ó $\sigma \sigma \varepsilon^{5}$ & $\operatorname{ainm}^{8}$ & $a k i^{12}$ & imeni, -е̌, oči & $*-i H_{1}$ \\
\hline gen.-loc. & pitrós & narà & 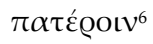 & athar ${ }^{9}$ & & kamenu & *- $H_{1} \mathrm{Ou}(\mathrm{s})$ \\
\hline $\begin{array}{l}\text { dat.-abl.- } \\
\text { ins. }\end{array}$ & pitŕobhyām & narabiia & & athr $(a) i b^{10}$ & akmeniñ $^{13}$ & kamenьma & $\begin{array}{l}{ }^{*}-b i i_{0} H_{1} \\
{ }_{-}-\mathrm{moH}_{1}\end{array}$ \\
\hline
\end{tabular}

Notes: see Beekes 1995: 194-95; Brugmann 1911: 294-97; 1) “two fathers"; 2) "two names"; 3) "two men"; 4) "two fathers", cf. Myc. pi-ri-je-te-re /prĭentēre/ "two sawers” (Bartoněk 2003, 255); 5) “eyes”. 6) Ending of o-stems (Rix 1976: 160). 7) Goid. *atere "two fathers”. 8) Goid. *anmen̄̄ "two names”. 9) Goid. *atrous? 10) Goid. *atribim. 11) OLith. žmune “two men” (Fortson 2004: 105). 12) “eyes”. 13) “to stones”. 13) “two stones”.

3. The issue of the origin of $o$-stems has been raised many times. Two hypotheses seem to rest on the best argumentative evidence:

3.1. Pedersen (1907: 152) mentioned that the subject of the transitive verb looked as if it had the form of the genitive (sigmatic case) if it was active, and as if it had the form of the instrumental case, if it was inactive. On the other hand, the subject and object of intransitive verbs seemed to have the form of the absolutive (i.e. asigmatic) case. This asymmetry between the valencies of transitive and intransitive verbs is summarized in Table 8 (see Beekes 1995: 193):

Table 8.

\begin{tabular}{c|l|l|l}
\hline \multicolumn{1}{c|}{ Verb } & \multicolumn{1}{|c|}{ Role } & \multicolumn{1}{c|}{ Nominative system } & \multicolumn{1}{c}{ Ergative system } \\
\hline \multirow{2}{*}{ transitive verb } & subject & nominative & ergative \\
\cline { 2 - 4 } & object & accusative & absolutive \\
\hline intransitive verb & subject & nominative & absolutive \\
\hline
\end{tabular}

Beekes (1985: 191-95; 1995: 193) and Kortlandt (2002: 217) have further developed Pedersen's idea, assuming that the nominative syntax of old Indo-European languages was formed later and that the case system of the Proto-Indo-European language was primarily based on the ergative syntax. The same ending for the nom. and acc. neuter, originally designating inactive nouns, originated from the primary absolutive case, while the ergative was correlated with the active subject. According to Beekes, the sigmatic genitive-ablative developed from the ergative. During the transformation of the ergative system into the nominative one, the form reconstructed as CC-R-ós became the nominative, a new case of subject; later, the vowel - 0 spread to other cases as well. Schmalstieg (1997: 401-07) and Gamkrelidze \& Ivanov (1984: 267-91, active typology) formulated their own theories assuming the ergative past of the IE syntax. For the implications of the ergative interpretation see Table 9.

3.2. Jean Haudry (1982: 36-38) formulated the idea that the $o$-stems originated from pronouns with a determining function that were added to a nominal base, thus playing the role of a postpositional article. For this solution there are typological parallels, e.g. in Balto-Slavic languages, where adjectives used in the attributive role are extended with the IE relative stem ${ }^{*} i o-{ }^{*} i \bar{a}-$; postpositional determination with the use of demonstratives is also active in modern 
Table 9.

\begin{tabular}{|c|c|c|}
\hline case & form $\left.{ }^{*}\right)$ & comments from the perspective of ergative interpretation \\
\hline \multirow{3}{*}{ sg. nom. } & $-\emptyset$ & in HD inflection and PD neuters (B 1985: 172) \\
\hline & $-s$ act. & identical with the sigmatic gen.-abl. sg., originally ergative (B 1985: 172-95) \\
\hline & -om inact. & $\begin{array}{l}\text { agens of the transitive verb (Pedersen 1907: 152; Schmalstieg 1997: 405-06: instr. of } \\
o \text {-stems) }\end{array}$ \\
\hline voc. & $-\emptyset$ & see B 1985: 99-108 \\
\hline acc. & $-m$ & originally directive-terminative (B 1985: 198) \\
\hline gen. & $-(0) s$ & originally ergative (B 1985: 172-95); in Hitt. used for both gen. sg. \& pl. \\
\hline \multirow{2}{*}{-"-o-st. } & -osio & < gen. *-os \& relative *io (B 1985: 185; Nikolaev 2000) \\
\hline & $-\bar{\imath}$ & cf. the suffix of affiliation *-iio- $\left({ }^{*}\right.$-iHo-?); see K 1994: 98-104; Meiser 1998: 135 \\
\hline abl. & $-O S$ & identical with the gen. sg. in *-(o)s, originally the ergative (B 1985: 172-95) \\
\hline -"-o-st. & $-(o / e) t / d(i)$ & cf. also Hitt. $-a z$ \\
\hline dat. & $-(e) i$ & on persons; dat. \& loc. were originally one and the same case (B 1995: 173) \\
\hline loc. & $-i$ & $\begin{array}{l}\text { on places \& inactive nouns; originally identical with the dative (B 1995: 173); cf. Arm. } \\
\text { herow, Gr. } \pi \dot{\varrho} \varrho v \sigma \mathrm{l}(\mathrm{v}) \text {, ON. í fjorð "last year", OIr. ón n-urid "from last year" < *per-uti } \\
\text { "year ago" }\end{array}$ \\
\hline instr. & $-H_{1}$ & cf. instr. pl. of the $o$-stems ${ }^{*}-\bar{o} i s<$ instr. sg. ${ }^{*}-o H_{1}+$ non-singular ${ }^{*}-o i-+$ pluralizing $-s$ \\
\hline pl. nom. & $-e s$ & \\
\hline \multirow{3}{*}{-"-o-st. } & $-o i$ & plural of pronominal origin \\
\hline & $-o i-$ & non-singular affix of the $o$-stems, preceding the case ending \\
\hline & $-H_{2}$ inact. & collective \\
\hline voc. & $=$ nom & \\
\hline acc. & $-m s$ & $=$ acc. sg. $-m+$ pluralizing $-s$ in congruence to the nom. pl. in $-e s$ \\
\hline gen. & $-o m$ & $\begin{array}{l}\text { see Kortlandt 1978; in Hitt. used in both gen. sg. \& pl.; Schmalstieg 1997: 405-06: erga- } \\
\text { tive }\end{array}$ \\
\hline abl. & $-i \operatorname{los}$ & 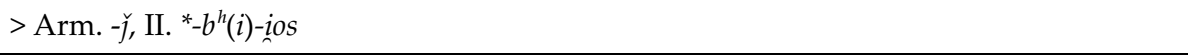 \\
\hline dat. & $-m u s$ & $>$ BSl. *-mus; Gmc. *-muz \\
\hline loc. & $-s u \sim-s i$ & $\begin{array}{l}\text { cf. Lat. mox, MWelsh moch "soon" < } m o k-s u \text {; Alb. abl. pl. -sh: malesh "in mountains"; për- } \\
\text { posh "down", posh-të "below" : oposh }{ }^{*} \text { "péd-si; Phryg. } \tau \varepsilon v \tau \omega \sigma \text { "in villages" (K 1994: } \\
\text { 313; H 2003: 129) }\end{array}$ \\
\hline instr. & $-b^{h} i$ & 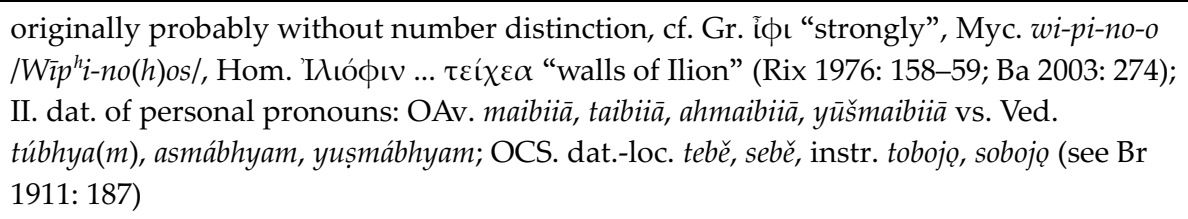 \\
\hline
\end{tabular}

N ot es: $\mathrm{B}$ = Beekes; $\mathrm{Ba}=$ Bartoněk; $\mathrm{Br}=$ Brugmann; $\mathrm{H}$ = Hajnal; $\mathrm{K}=$ Klingenschmitt. Identification of non-singular morpheme *-oi- and pluralizer $-s$ in some cases imply an agglutinative structure.

Balkanian or Scandinavian languages. So-called mimation \& nunation in Semitic languages also generally represent postpositional determination. In Indo-European, a good ancestral candidate could be identified in the Anatolian pronoun - $a$ - of the 3rd person, attested only in postposition (HEG 1-2, 6-7): Table 10. 
Table 10.

\begin{tabular}{l|l|l|l|l|l|l}
\hline case & \multicolumn{1}{|c|}{ Hittite } & \multicolumn{1}{|c|}{ Palaic } & C. Luwian & Hier. Luwian & Lydian & $*$ \\
\hline nom. sg. c. & $-a s$ & $-a s$ & $-a s$ & $-(a) s$ & $-a s$ & ${ }^{*}$-os \\
\hline nom.-acc. sg. n. & $-a t$ & $-a t$ & $-a t a$ & $-(a) t a$ & $-a d,-a t$ & ${ }^{*}$-ot \\
\hline acc. sg. c. & $-a n /-u n$ & $-a n$ & $-a n$ & $-a n$ & $-a v$ & ${ }^{*}$-om \\
\hline nom. pl. c. & $-e$ & $-a s$ & & & & ${ }^{*}$-oi \\
\hline nom.-acc. pl. n. & $-e$ & $-e$ & & & & ${ }^{*}$ oi \\
\hline acc. pl. c. & $-u s$ & & $-a t a$ & $-(a) t a$ & & ${ }^{*}$-oms \\
\hline acc. pl. n. & $-a t$ & & ${ }^{*}$-ot \\
\hline
\end{tabular}

4. While summarizing the preceding partial reconstructions, it becomes apparent that the most difficult task is to establish the original protoforms of the ablative, dative and instrumental plural. It is natural to suppose some mutual levelling, merging, and contamination. These processes are summarized in Table 11 (see Brugmann 1911: 120; Beekes 1985: 144-46), whence the following case protosystem may be postulated (Table 12) to explain the partial case systems in daughter branches.

5. Internal reconstruction should be followed with external comparison. Interpretations are possible on both typological and genetic levels, provided that the Proto-Indo-European language was not completely isolated.

5.1. Semitic noun inflection uses forms both with and without determination, the latter expressed with the postpositional article in the form *-m ('mimation') or * $n$ ('nunation'). See Table 13 (Dolgopolsky 1991; Lipiński 1997; Blažek 2006).

5.1.1. Semitic languages form one branch of the Afroasiatic macrofamily. Table 14 summarizes the correspondences in case endings, prepositions \& postpositions between the (sub)branches of AA.

5.2. Another language family in the neighborhood of Indo-European is Kartvelian. Its nominal declension is a transparent case of the agglutinative model, cf. the paradigm of * $\mathrm{kac}^{-}$ "man": Table 15.

5.3. Another important language family in the neighborhood of Indo-European is Uralic. The agglutinative structure is also typical for Uralic languages.

5.3.1. The nominative has been reconstructed as unmarked in the Uralic protolanguage. However, it is remarkable that in several Fenno-Ugric languages a special nominative form was generated out of demonstratives or demonstrative suffixes of the $3^{\text {rd }}$ person according to the scenario described by Haudry in connection with the $o$-stem IE nominative in ${ }^{*} s(\S 3.2)$ : Table 16.

5.3.2. Other cases are represented in the Uralic languages as follows: Table 17.

6. Finally, from the point of view of the Nostratic theory of V. M. Illich-Svitych, A. Dolgopolsky and other scholars, it is legitimate to compare the Proto-Indo-European case system with reconstructed case systems of neighboring language families so as to establish the number of common inherited morphemes: Table 18. 
Table 11.

\begin{tabular}{l|l|l|l|l|l|l|l|l|l}
\hline case & IE & II & Arm. & Gr. & Messap. & Italic & Celtic & Gmc. & BSl. \\
\hline dat. pl. & ${ }^{*}-$ mus & & & & & & & & ${ }^{*}-m u s$ \\
\hline$>$ & & & & & & & & ${ }^{*}-m o s$ & \\
\hline abl. pl. & ${ }^{*}-i o s$ & & $-j^{2}$ & & & & & & \\
\hline$>$ & & ${ }^{*}-b^{h} i o s$ & & & $-b i s^{3}$ & ${ }^{*}-b^{h} o s$ & ${ }^{*}-b^{h} o s$ & & \\
\hline ins. pl. & ${ }^{*}-b^{h} i^{1}$ & ${ }^{*}-b^{h} i s$ & ${ }^{*}-b^{h} i(s)$ & ${ }^{*}-b^{h} i$ & & & ${ }^{*}-b^{h} i(s)$ & & \\
\hline$>$ & & & & & $-b a s^{4}$ & & ${ }^{*}-m i^{5}$ & ${ }^{*}-m i s^{6}$ & ${ }^{*}-m i H s$ \\
\hline dat. pl. & ${ }^{*}-m u s$ & & & & & & & & \\
\hline
\end{tabular}

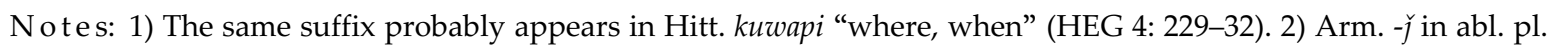
of personal pronouns mēnj, jēnǰ is derivable from *-ios (Kortlandt 1984: 103-04=2003, 50; Beekes 1985: 144). 3) Messap. abl. pl. ogrebis, tatӨebis, valeabis (see MLM II). 4) Messap. dat. pl. Laidehiabas, Logetibas. 5) Cf. the OIr. dat. pl. $n$-stems of the type anm(a)imm from ainm "name"; already Brugmann (1911: 188) thought about this solution and Hamp (1996) later returned to it. 6) See WGmc. dat. pl. Vatvims \& Aflims, corresponding to Lat. Vatviabus \& Afli-

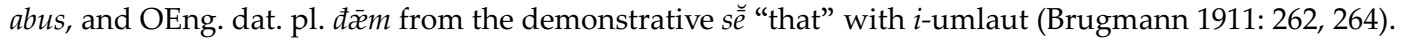

Table 12.

\begin{tabular}{|c|c|c|c|c|c|c|}
\hline \multirow{2}{*}{$\begin{array}{l}\text { number } \\
\text { case / type }\end{array}$} & \multicolumn{2}{|c|}{ singular } & \multicolumn{2}{|c|}{ plural } & \multicolumn{2}{|c|}{ dual } \\
\hline & athematic & thematic & athematic & thematic & athematic & thematic \\
\hline nom. anim. & $*-S$ & ${ }^{*}-O S$ & *es & ${ }^{*}-\bar{o} s<{ }^{*}-o-e s$ & $*-H_{1}$ & ${ }^{*}-\mathrm{o}-\mathrm{H}_{1}$ \\
\hline voc. & $*-\emptyset$ & $*-e$ & $*$-es & ${ }^{*}-\bar{o} S<{ }^{*}$-o-es & ${ }^{*}-H_{1}$ & ${ }^{*}-\mathrm{o}-\mathrm{H}_{1}$ \\
\hline acc. anim. & $*-m$ & ${ }^{*}$-om & $*-m s$ & ${ }^{*}$-oms & ${ }^{*}-H_{1}$ & ${ }^{*}-o-H_{1}$ \\
\hline nom.-acc. n. & $*-\emptyset$ & ${ }^{*}$-om & ${ }^{*}-\mathrm{H}_{2}$ & ${ }^{*}-e H_{2}$ & ${ }^{*}-i H_{1}$ & ${ }^{*}-O-i H_{1}$ \\
\hline gen. & $*_{-S}$ & ${ }^{*}-o s(-i o)$ & ${ }^{*}$-om & $*_{-o} m$ & ${ }^{*}-H_{1} \overline{o s}$ & ${ }^{*}-o i-H_{1} \overline{o s}$ \\
\hline abl. & $*-S$ & ${ }^{*}-\bar{o} d<{ }^{*}$-o-ed & $*-i o s$ & $*_{-O L}$ - OS & $=$ dat. & $=$ dat. \\
\hline dat. & $*-e i$ & ${ }^{*}-\bar{o} i{ }_{n}<{ }^{*}-O-e \underline{r}$ & ${ }^{*}-m u s$ & ${ }^{*}-o i-m u s$ & ${ }^{*}-m \bar{o} H_{1}$ & ${ }^{*}-o i-m \overline{-} \mathrm{H}_{1}$ \\
\hline loc. & ${ }^{*}-i$ & *-oi & ${ }^{*}-s u$ & ${ }^{*}-o i-s u$ & ${ }^{*}-\mathrm{H}_{1} \mathrm{Ou}$ & ${ }^{*}-\mathrm{oi}-\mathrm{H}_{1} \mathrm{Ou}$ \\
\hline instr. & $*-H_{1}$ & ${ }^{*}-o H_{1}$ & ${ }^{*}-b^{h} i(s)$ & ${ }^{*}-o i-b^{h} i(s)$ & ${ }^{*}-b^{h} i H_{1}$ & ${ }^{*}-o i-b^{h} i H_{1}$ \\
\hline
\end{tabular}

Notes: see Beekes 1995: 173; Fortson 2004: 113. 
Table 13.

\begin{tabular}{|c|c|c|c|c|c|c|c|c|c|c|c|}
\hline case & * Sem. & Akk. & ${ }^{*}$ Ebl. & Amarna & Ugar. & Hebr. & Aram. & ClArab. & EpNAr. & EpSAr. & Geez \\
\hline \multicolumn{12}{|c|}{ sg. indet. } \\
\hline nom. & $-u$ & $-\emptyset$ & & & $-u(m ?)$ & $-\emptyset$ & $-\emptyset$ & $-u$ & & $-V$ & \\
\hline acc. & $-a$ & $-\emptyset$ & & & $-a(m ?)$ & $-\emptyset$ & $-\emptyset$ & $-a$ & & $-V$ & $-a$ \\
\hline gen. & $-i$ & $-\emptyset$ & & & $-i(m ?)$ & $-\emptyset$ & $-\emptyset$ & $-i$ & & $-V$ & \\
\hline loc. & $-u m a$ & $-u m$ & $-\bar{u} m$ & $-a m a$ & $-V m V$ & $-o m$ & $-\bar{u}$ & $-u$ & & & $-u$ \\
\hline $\begin{array}{l}\text { dir.- } \\
\text { dat. }\end{array}$ & $-a / i \check{s}$ & $-i \check{S}$ & $-i \check{S}$ & & $-h$ & $-\bar{a}(h)$ & & & & & \\
\hline pred. & $-a$ & $-\emptyset$ & $-a$ & & & $-\emptyset$ & $-\emptyset$ & $-a$ & & & $-a$ \\
\hline \multicolumn{12}{|c|}{ sg. det. } \\
\hline nom. & $-u-m$ & $-u m$ & $-u m$ & & $-u(m)$ & $-\emptyset$ & -0 & -un & & $-V m$ & $-\emptyset$ \\
\hline acc. & $-a-m$ & $-a m$ & $-a(m)$ & & $-a(m)$ & $\begin{array}{l}-\emptyset ; \mathrm{adv} . \\
-\bar{a} m\end{array}$ & $\begin{array}{l}-\emptyset ; \\
\mathrm{adv} .-\bar{a}\end{array}$ & $-a n$ & & $-V m$ & $-a$ \\
\hline gen. & $-i-m$ & $-i m$ & $-i m$ & & $-i(m)$ & $-\emptyset$ & $-\emptyset$ & $-i n$ & & $-V m$ & $-\emptyset$ \\
\hline \multicolumn{12}{|c|}{ du. indet. } \\
\hline nom. & $-\bar{a}$ & $-\bar{a}$ & $-\bar{a}$ & & $|-\bar{a}|$ & & & $-\bar{a}$ & & & \\
\hline $\begin{array}{l}\text { acc.- } \\
\text { gen. }\end{array}$ & $-a y$ & $-\bar{\imath}$ & & & $|-\bar{e}|$ & $-\bar{e}$ & $-\bar{e}$ & $-a y$ & $-a y$ & $-y$ & \\
\hline pred. & $-\bar{a}$ & $-\bar{a}$ & & & & & & $-\bar{a}$ & & & \\
\hline \multicolumn{12}{|c|}{ du. det. } \\
\hline nom. & $-\bar{a}-n i$ & $-\bar{a} n$ & $-\bar{a} n$ & & $\begin{array}{l}-m \\
|-\bar{a} m i|\end{array}$ & $-m$ & & $-\bar{a} n i$ & $-n$ & $\begin{array}{l}-n(y) \\
\text { Q. -my }\end{array}$ & \\
\hline $\begin{array}{l}\text { acc.- } \\
\text { gen. }\end{array}$ & $-a y-n i$ & $-\bar{i} n$ & $-a y n$ & $-\bar{e} m a / i$ & $\begin{array}{l}-m \\
|-\bar{e} m i|\end{array}$ & -áyim & & -ayni & & $-y n$ & \\
\hline \multicolumn{12}{|c|}{ pl. A indet. } \\
\hline nom. & $-\bar{u}$ & $-\bar{u}$ & $-\bar{u}$ & & $-u|-\bar{u}|$ & & Yu. $-w$ & & & & \\
\hline $\begin{array}{l}\text { acc.- } \\
\text { gen. }\end{array}$ & $-\bar{\imath}$ & $-\bar{\imath}$ & $-\bar{\imath}$ & & $-i|-\bar{\imath}|$ & & Yu. $-y$ & $-\bar{\imath}$ & & & \\
\hline pred. & $-\bar{u}$ & $-\bar{u}$ & & & & $-\bar{u}$ & & $-\bar{u}$ & & $-w$ & $-\bar{u}$ \\
\hline \multicolumn{12}{|c|}{ pl. A det. } \\
\hline nom. & $-\bar{u}-m a$ & & & & $\begin{array}{l}-u m(a) \\
|-\bar{u} m a|\end{array}$ & & & $-\bar{u} n a$ & & & \\
\hline $\begin{array}{l}\text { acc.- } \\
\text { gen. }\end{array}$ & $-\bar{\imath}-m a$ & & & & $\begin{array}{l}\text {-im(a) } \\
\text { /-imal }\end{array}$ & $-\bar{\imath} m$ & $-\bar{i} n$ & $-\bar{i} n a$ & & $-V n V$ & \\
\hline \multicolumn{12}{|c|}{ pl. B indet. } \\
\hline nom. & $-\bar{a} t-u$ & $-\bar{a} t$ & & & $-t$ & $-\bar{o} \underline{t}$ & $-\bar{a} \underline{t}$ & $-\bar{a} t u$ & & & \\
\hline $\begin{array}{l}\text { acc.- } \\
\text { gen. }\end{array}$ & $-\bar{a} t-i$ & $-\bar{a} t$ & & & $-t$ & $-\bar{o} \underline{t}$ & $-\bar{a} \underline{t}$ & $-\bar{a} t i$ & & & \\
\hline pred. & $-\bar{a}$ & $-\bar{a}$ & & & & & $-\bar{a}$ & $-\bar{a}$ & & & $-\bar{a}$ \\
\hline \multicolumn{12}{|c|}{ pl. B det. } \\
\hline nom. & $\begin{array}{l}-\bar{a} t-u- \\
m\end{array}$ & $-\bar{a} t u m$ & $-\bar{a} t u m$ & & $-t$ & $-\bar{o} t$ & & $-\bar{a} t u n$ & & & $-\bar{a} t$ \\
\hline $\begin{array}{l}\text { acc.- } \\
\text { gen. }\end{array}$ & $-\bar{a} t-i-m$ & -ätim & -ātim & & $-t$ & $-\bar{o} t$ & & -ātin & & & $-\bar{a} t$ \\
\hline
\end{tabular}


Table 14.

\begin{tabular}{|c|c|c|c|c|c|c|c|c|c|}
\hline Semitic & Egyptian & Berber & Cushitic: & Beja & Agaw & ECush. & Dah. & SCush. & Omotic \\
\hline \multirow[t]{2}{*}{$*-u^{1}$} & ${ }^{*}-u^{1}$ & & $*-u^{24}$ & ${ }^{*}-u^{24} ?$ & & $*-u^{24}$ & & & $*-u^{1}$ \\
\hline & & & $*-i^{24}$ & or ${ }^{*}-i^{24} ?$ & $*-i^{24}$ & $*-i^{24}$ & & & ${ }^{*}-i /-y^{1}$ \\
\hline$*-i^{2}$ & $*-i^{2}$ & $*-i^{5}$ & $*-i^{2}$ & $-i^{2}$ & $*-i^{2}$ & & & & $*-i^{2}$ \\
\hline \multirow[t]{2}{*}{$*-a^{3}$} & $*-a^{3}$ & $*-a^{3 a}$ & $*-a^{25}$ & $*-a^{25} ?$ & $*-a^{25}$ & $*-a^{25}$ & & $-a^{43}=3 a ?$ & ${ }^{*}-a^{25}$ \\
\hline & & $* \bar{\imath} / \partial y^{19}$ & $*-226$ & $-i(i)^{2=30} ?$ & & $*-226$ & $-2 i^{31}$ & $* i^{41}$ & \\
\hline$*-a / i \breve{s}^{4}$ & $j s^{14}$ & $* \partial S^{20}$ & ${ }^{*}-s a / i^{27}$ & $-s^{35}$ & $*-s^{26}$ & ${ }^{*}-s a / i^{27}$ & & ${ }^{*} \mathrm{Sa}^{44}$ & $*-s^{26}$ \\
\hline${ }^{*}-u m a^{5}$ & $m^{15}$ & & ${ }^{*}-m a^{42}$ & & & ${ }^{*}-m a^{42}$ & & $?^{*} m a a^{48}$ & ?A. ${ }^{*}-m^{51}$ \\
\hline${ }^{*} k a^{6}$ & & & ${ }^{*}-k V^{28}$ & $-k a^{36}$ & & ${ }^{*}-k V^{28}$ & & ${ }^{*} k_{0 o}{ }^{44}$ & $*-k V^{45}$ \\
\hline${ }^{*} l a / i^{7}$ & $n j^{16}$ & & $*-l a / i^{29}$ & & $*-l i^{29}$ & $*-l a / i^{29}$ & & *-2ilay ${ }^{40}$ & \\
\hline${ }^{*}$ adi ${ }^{8}$ & & $* d \partial y^{21}$ & $*-d i^{29}$ & $-d /-t^{37} ?$ & $*-d i^{40}$ & ${ }^{*}-d(d) i^{29}$ & $-d a^{29}$ & $*-r^{49}$ & \\
\hline *?ittu/i/a9 & & & $*-t t i^{30}$ & $-d /-t^{37} ?$ & & $*-t t i^{30}$ & & & Ye. $-t \grave{a}^{5}$ \\
\hline$*$ ina $^{10}$ & $j n^{17}$ & ${ }^{*} \mathrm{Hin}^{22}$ & $*-n a / i^{31}$ & $\begin{array}{l}-n a^{38} \\
-n e e^{39}\end{array}$ & & ${ }^{*}-n i^{31}$ & & & ${ }^{*}-n V^{46}$ \\
\hline *ar-11 & $j r^{18}$ & ${ }^{*} H \bar{a} r^{23}$ & $* 2 a r-32$ & & & *?ar 32 & & *hari ${ }^{45}$ & ${ }^{*}-r V^{47}$ \\
\hline$* w a^{12}$ & & & $*-w a^{33}$ & & ${ }^{*}-w a^{41}$ & ${ }^{*}-w a^{32}$ & & ${ }^{*} w a^{39}$ & $*-u /-w^{26}$ \\
\hline${ }^{*} b a / i^{13}$ & & & $*-b^{34}$ & $-b^{34}$ & & h. - beyyo & & & \\
\hline$*-a y^{52+53}$ & $-j^{53}$ & & & & $*-i^{54}$ & & & & \\
\hline
\end{tabular}

Notes: see Blažek 2006; 1 nominative, 2 genitive, 3 accusative, 3a adverbial accusative, 4 dative-terminative, 5 locative, 6 simulative ("as, like”)-comitative (“with”), 7 “to", 8 “up to", 9 comitative ("with”), 10 locative-inessive ("in, on"), 11 Jibbali 'Er “towards", 12 “and”, cf. Arabic wa-llāhi "by God” (Sasse 2003: 139), 13 locative ("in, at, by"), 14 "as", 15 “in, with, from; as", 16 "belonging to", cf. Coptic la "possessing”, 18 "by", cf. Coptic (S) ara- "to, at; for", 19 dative ("to" = “à"), 20 "to, at, by”, 21 “in (the middle), inside”, 22 "in, at, to", 23 "to, till, as far as", 24 subject, 25 absolutive $=$ object, 26 dative, 27 dative-benefactive, 28 dative-simulative, 29 locative, 30 locativeablative-instrumental, 31 instrumental, 32 allative-directive ("towards"), 33 adessive-directive, 34 adessive-ablative, 35 locative-genitive, 36 comparative, 37 simulative ("as”), 38 instrumental, 39 ablative, 40 comitative, 41 directiveallative, 42 Dullay "to", 43 in adverbs of the type of Proto-Iraqw *gawáa "on" vs. West Rift *gaba "summit, top of the mountain", Proto-Iraqw *afáa "by, beside" vs. West Rift *afa "mouth", 44 causal-benefactive, 45 instrumentaldirective, 46 instrumental-directive-locative, 47 comitative-dative, 48 Alagwa maa "then, afterwards" (Kiessling 2002: 377), 49 - $r$ in *dír "by, on", derived from *dii "place”, or ?amór "by, on", from *amoo "way" (Kiessling 2002: 424-25), 50 directive, 51 direct object, 52 Hebr. $-\bar{e}$ pl. in status constructus m., Aram. -e pl. in status determinus, 53 dual, 54 e.g. Kemant azi pl. from aza "fish"; cf. Chadic *-ay pl. (Illič-Svityč 1971: 285). 
Table 15.

\begin{tabular}{|c|c|c|c|c|c|c|}
\hline \multicolumn{2}{|c|}{$\begin{array}{l}\text { case / } \\
\text { number }\end{array}$} & Georgian & Laz & Mingrelian & Svan & Kartvelian \\
\hline \multirow[b]{2}{*}{ nom. } & sg. & $k a c-i$ & $k \circ c ̌-i$ & $k \circ \iota^{-}-i$ & çäš & nom. ${ }^{*}-i($ F 211) \\
\hline & pl. & $k a c-e b-i / k a c-n-i$ & koč-ep-e & $k o c ̌-e p-i$ & çäs̆-är & $\begin{array}{l}\text { pl. *-eb (F 145) } \\
\text { pl. *-n (F 311) } \\
\text { pl. *-ar (F 38) }\end{array}$ \\
\hline \multirow{2}{*}{ erg. } & sg. & kac-ma & $k o c ̌-i k$ & $k o c ̌-k$ & 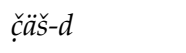 & \\
\hline & pl. & $k a c-e b-m a / k a c-t a$ & koč-epe-k & $k o c ̌-e(n)-k$ & çäs̆-är-d & \\
\hline \multirow{2}{*}{ dat. } & sg. & $k a c-s(a)$ & $k o c ̌-i s$ & kos / koc & çăš-s & dat. ${ }^{*}-s$ (F 358) \\
\hline & pl. & $k a c-e b-s(a) / k a c-t a$ & koč-epe-s & $k o c ̌-e(n)-s$ & çäs̆-är-s & \\
\hline \multirow{2}{*}{ gen. } & sg. & $k a c-i s(a)$ & $k o c ̌-i s ̌(i)$ & $k o c ̌-i s ̌(i)$ & çäš-i(š) & gen. ${ }^{*}-i s_{1}$ (F 215) \\
\hline & pl. & $k a c-e b-i s(a) / k a c-t a$ & $k o c ̌-i s ̌(i)$ & $k o c ̌-e p-i \check{s}(i)$ & 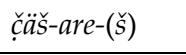 & \\
\hline \multirow[t]{2}{*}{ dir. } & sg. & $k a c-a d(a)$ & $k o c ̌-i s ̌ a$ & $\begin{array}{l}\operatorname{tran} . \text { koč-o } \\
k o c ̌-i s ̌ a\end{array}$ & çăš-d & $\begin{array}{l}\text { advr. }{ }^{*} \text {-ad (F 32) } \\
\text { dir. }{ }^{*}-i s_{1}-a(\text { F 215) }\end{array}$ \\
\hline & pl. & $k a c-e b-a d(a)$ & koč-epe-ša & $k o c ̌-e p-i s ̌ a$ & čäš-är-d & \\
\hline \multirow{2}{*}{ abl. } & sg. & $=$ dir. & koč-iše $(n)$ & koč-iše & - & \\
\hline & pl. & $=$ dir. & koč-epe-še $(n)$ & koč-ep-iše & - & \\
\hline \multirow{2}{*}{ instr. } & sg. & $k a c-i t(a)$ & koč-ite $(n)$ & koč-it $(i)$ & çäš-šw & instr. ${ }^{*}$-it (F 213) \\
\hline & pl. & $k a c-e b-i t(a)$ & koč-epe-te $(n)$ & $k o c ̌-e p-i t(i)$ & čăš-är-šw & \\
\hline \multirow{2}{*}{ fin. } & sg. & 3vel-isad & - & $k \circ \operatorname{cc}^{-i s ̌ o}(t)$ & 亏̌winel-išd & dir. ${ }^{*}-i s_{1}-d$ (F 215) \\
\hline & pl. & 3vel-eb-isad & - & $k o c ̌-e p-i \check{s} o(t)$ & 亏̌winel-är-išd & \\
\hline \multirow{2}{*}{ tran. } & sg. & $=\operatorname{dir}$ & - & koč-o & $=$ dir. & \\
\hline & pl. & $=$ dir. & - & koč-ep-o & $=$ dir. & \\
\hline \multirow{2}{*}{ voc. } & sg. & kac-o & - & - & - & \\
\hline & pl. & $k a c-e b-o /-n-o$ & - & - & - & \\
\hline
\end{tabular}

N otes: See Jost Gippert <http://titus.uni-frankfurt.de>; on reconstructions, see Fähnrich 2007 = F.

Table 16.

\begin{tabular}{|c|c|c|c|c|c|}
\hline language & indet. sg. & det. sg. & indet. pl. & det. pl. & origin of suffix \\
\hline Mordvin & tolga "feather" & tolgaś "that f." & tolgat "feathers" & tolgat'ñä "those f." & $\begin{array}{l}\text { śä, śe "that" : } \\
n e \text { "these" }\end{array}$ \\
\hline Udmurt & $i z$ "stone" & izez "that s." & izjos "stones" & izjosiz "those s." & $\begin{array}{l}-z \text { suffix of } 3 r d \\
\text { person sg. }\end{array}$ \\
\hline Komi & vok "brother" & vokis "that b." & vokjas "brothers" & vokjasiz "those b." & $\begin{array}{l}\text {-s suffix of 3rd } \\
\text { person sg. }\end{array}$ \\
\hline
\end{tabular}

Note s: See Szinnyei 1910: 62. 
Table 17.

\begin{tabular}{|c|c|c|c|c|c|c|c|c|c|}
\hline case & Ural./FU & BFin. & Saami & Mordvin & Mari & Permic & Hung. & Ob-Ugr. & Samoy. \\
\hline gen. & $*-n$ & $*-n$ & $*-n$ & $-n$ & $-n$ & & & & $*-n$ \\
\hline acc. & ${ }^{*}-m$ & $*-n$ & ${ }^{*}-m$ & $-n$ & $-m$ & & \multicolumn{2}{|c|}{ Ugr. ${ }^{*}-m p^{4}$; Ma. ${ }^{*}-m V$} & $*-m$ \\
\hline loc. & ${ }^{*}-n a l^{*}-n \ddot{a}$ & ${ }^{*}-\left.n a\right|^{*}-n \ddot{a}$ & $*-n \bar{e}$ & -ńal-ńe & $-n a$ & $-y n$ & $-n$ & ${ }^{*}-n V$ & ${ }^{*}-n V$ \\
\hline loc. & $*-t t i$ & $\begin{array}{l}* \text { *ttik, } \\
* \text {-ten }\end{array}$ & & $-t^{\prime}$ & $-t$ & tran. $-t i$ & $-t t$ & $-t$ & \\
\hline abl. & ${ }^{*}-\delta a l^{*}-\delta \ddot{a}$ & ${ }^{*}-\delta a{ }^{*}-\delta \ddot{a}^{1}$ & $*-\delta \bar{e}$ & $-d o$ & $-c^{\prime}$ & & & & $*-\delta$ \\
\hline $\begin{array}{l}\text { dat.- } \\
\text { lative }\end{array}$ & ${ }^{*}-n \dot{i}$ & $\begin{array}{l}\text { Fi. }-n^{2} \\
\text { Est. }-n i^{3}\end{array}$ & & & $-n$ & $*-n$ & $-n y i$ & $*-n a$ & $*-n i$ \\
\hline lative & ${ }^{*}-k a l^{*}-k \ddot{a}$ & $*-k$ & $*-k \bar{e}$ & $-v a$ & $-k a$ & *-e & $-e^{\prime},-a$ & $*-\gamma$ & \\
\hline lative & $*_{-j}$ & $\begin{array}{l}\text { Fi. }-i \\
\text { Est. }-j a\end{array}$ & & & & $*-i$ & -é & Kh. $-j,-i$ & \\
\hline lative & $*-s^{5}$ & $*-s$ & $*-s$ & $-s$ & $-\check{s}$ & & & & \\
\hline pl. & $*-t$ & $*-t$ & $*-t$ & $-t$ & $-t$ & & & $*-t$ & $*-t$ \\
\hline pl. & $*-j-6$ & $*_{-i-}$ & $*_{-i-}$ & & & & $-i^{7}$ & & $*_{-i}$ \\
\hline pl. & $*-n-8$ & $*-n-$ & & & & & & & $*-n$ \\
\hline du. & ${ }^{*}-k a{ }^{*}-k \ddot{a}$ & & *-kâ & & & & kettő “2” & $*-\gamma-(\partial n)$ & ${ }^{*}-k V$ \\
\hline
\end{tabular}

Note s: see Collinder 1960: 282-303; Hajdú 1985: 292-311; Hofírková \& Blažek 2012; Szinnyei 1910: 63-84; 1) Partitive. 2) Archaic dative-genitive: Jumala- $n$ kiitos “thank god”. 3) Terminative. 4) Ugr. ${ }^{*}-m p<$ acc. ${ }^{*}-m+$ pronoun of the 3rd person sg. *sa/*sä. 5) Szinnyei 1910: 71-72. 6) Plural of oblique cases. 7) Cf. Hung. kez-e "his hand" : kez-e-i "his hands”. 8) Pronominal. 9) Attributive ket : absolutive kettő Mansi kiti , E.Khanty kätkan "2" with the dual suffix. 
Table 18.

\begin{tabular}{|c|c|c|c|c|c|c|}
\hline case & $\left.\operatorname{IE}{ }^{*}\right)$ & Afroasiatic & Kartvelian & Uralic & Altaic & Dravidian \\
\hline \multirow{4}{*}{ sg. nom.-voc. } & $-\emptyset$ & & & $\emptyset$ & $\emptyset$ & $\emptyset$ \\
\hline & $i$ - \& $u$-stems & ${ }^{*}-i \&{ }^{*}-u$ & ${ }^{*}-i$ & & & $* i$ \\
\hline & -s act. & & & & & \\
\hline & -om inact. & & & & & ${ }^{*}-m{ }^{*}-n$ inact. \\
\hline acc. $<$ term. & $-m$ & $\begin{array}{l}\text { ?loc.-dir. } \\
{ }^{*}-(u) m a\end{array}$ & & acc. ${ }^{*}-m$ & $*(-) b e$ & ${ }^{*} a m /{ }^{*}-a n$ \\
\hline gen.-abl. & $-(o) s$ & $\begin{array}{l}\text { ?dat.-term.- } \\
\text { dir. }{ }^{*}-i s(a)\end{array}$ & gen. ${ }^{*}-i s_{1}$ & & & \\
\hline $\begin{array}{l}\text { gen. } \\
\text { (o-stems) }\end{array}$ & $-\bar{\imath}$ & gen. ${ }^{*}-i$ & & & & $\begin{array}{l}\text { gen. }{ }^{*}-i \\
\text { (Gond.) }\end{array}$ \\
\hline abl. (o-stems) & $-(o / e) t / d(i)$ & $\begin{array}{l}\text { loc.-abl.-instr.- } \\
\text { com. }{ }^{*} \text {-itt } V\end{array}$ & instr. ${ }^{*}$-it & loc. ${ }^{*}-t t i$ & & $\begin{array}{l}\text { gen. obl. } \\
*_{-}(t) t u\end{array}$ \\
\hline dat.-loc. & $-(e) i$ & $\begin{array}{l}\text { dat.-loc.-abl. } \\
\text { *-iy }\end{array}$ & & lative ${ }^{*}-j$ & & ?acc. *-ay \\
\hline loc. heter. & $-e n^{1}$ & $\begin{array}{l}\text { instr.-dir.-loc.- } \\
\text { abl. }{ }^{*}-n a / i\end{array}$ & & loc. ${ }^{*}-n a{ }^{*}-n \ddot{a}$ & $\begin{array}{l}\text { dat.-instr. } \\
{ }^{*} n V\end{array}$ & $\begin{array}{l}\text { loc. }{ }^{*}-i n /{ }^{*}-i l \\
\text { instr. }{ }^{*}-\bar{a} n\end{array}$ \\
\hline advr. & $-d^{h} i,-d^{h} e^{2}$ & loc.-com. ${ }^{*}-d i$ & advr. ${ }^{*}-a d$ & $\mathrm{abl} .{ }^{*}-\delta a{ }^{*}-\delta \ddot{a}$ & $\begin{array}{l}\text { dat.-loc. } \\
*-d a /{ }^{*}-d u\end{array}$ & soc. *-ŏțu \\
\hline instr. & $-H_{1}$ & dat.-instr. ${ }^{*}-2 i$ & & & & $\begin{array}{l}\text { instr. }{ }^{*}-\bar{e} \\
\text { (Gond.) }\end{array}$ \\
\hline pl. nom. & -es & & & & $*_{-s-}$ & \\
\hline \multirow{2}{*}{-"-o-stems } & $-o i$ & du. ${ }^{*}-a y-$ & & & & \\
\hline & -oi- obl. & $*-a y^{4}$ & & pl. obl. ${ }^{*}-j-4$ & & \\
\hline pl. nom.-acc. & $-H_{2}$ inact. & pl.-coll. ${ }^{*}-\bar{a} h^{3}$ & & & & pl. ntr. ${ }^{*}-a$ \\
\hline acc. & $-m s<{ }^{*}-s-m ?$ & & & & & \\
\hline gen. & $-o m$ & & ?Ge. erg. - ma & & & \\
\hline dat. & $-m u s$ & $\begin{array}{l}\text { ?loc.-dir. } \\
\text { *-(u)ma }\end{array}$ & & & & \\
\hline loc. & $-s u \sim-s i$ & $\begin{array}{l}\text { ?dat.-term.- } \\
\text { dir. }{ }^{*}-i s(a)\end{array}$ & $\begin{array}{l}\text { dat. }{ }^{*}-s \text { or } \\
\text { Svan instr. } \\
-s ̌ w<{ }^{*} s_{1} w V ?\end{array}$ & lative ${ }^{*}-s$ & & \\
\hline instr. & $-b^{h} i$ & $\begin{array}{l}\text { loc.-abl.-dir. } \\
*(-) b a / *(-) b i\end{array}$ & & & & \\
\hline
\end{tabular}

Notes: 1) Base of the oblique cases of heteroclitics, originally probably locatives of the type of Vedic udán "in wa-

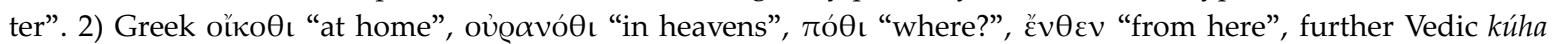
“where?”, Old Avestan kudā, Old Church Slavonic kbde id., sbde "here” etc. (Brugmann 1911: 167, 728). 3) Semitic

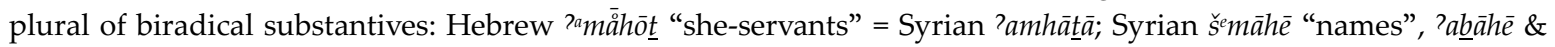
?ạbāhātāa "fathers" = Arabic ?abahāt; Arabic sitāh "backs", šifāh "lips", šiyāh "sheep" (pl.), miyāh "waters"; further ’ilāh "god" (pl.) = Hebrew ^elōhim, Syriac ?allāhā (Brockelmann 1908: 455). Cushitic plural in *-a is probably of the same origin. 4) Illič-Svityč 1971: 285-86: IE+AA+Uralic; Kortlandt 2002: 217: IE. * -oi--+ Uralic *-j-. 
Conclusion. Aharon Dolgopolsky (2005: 35) used to wonder if the original grammatical structure of Nostratic was synthetic or analytic. The present analysis of the Indo-European nominal inflection in Nostratic context confirms his preference of the analytic structure, with regard to the fact that most of the Indo-European case endings are derivable from various deictic or adverbial particles, some on the Indo-European level (usually with Nostratic roots), e.g. loc. sg. in -en- (Skt. udán) vs. ${ }^{*} H_{1} e n$ - "in", others on the Nostratic level at least, e.g. loc. pl. in *-su vs. Kartvelian *šuwa- "in the middle” or Central Cushitic *šzw- "heart” (Dolgopolsky 2005: 17-19).

\section{Abbreviations}

A. - Aroid, ab(l). - ablative, abs. - absolutive, adj. - adjective, adv. - adverb, advr. - adverbialis, Aeol. Aeolic, acc. - accusative, Akk. - Akkadian, Alb. - Albanian, act. - active, Ar. - Arabic, Aram. - Aramaic, Arg. - Argive, arch. - archaic, Arc. - Arcadian, Arm. - Armenian, Att. - Attic, Av. - Avestan, Balt. - Baltic, BFin. - Balto-Finnic, Bret. - Breton, BSl. - Balto-Slavic, c. - genus communis, Celt. - Celtic, Clb. - Celtiberian, Cl. - Classic, col. - collective, com. - comitative, cons. - consonantic, Copt. - Coptic, Corn. - Cornish, Cret. - Cretan, Cush. - Cushitic, Cz. - Czech, Dah. - Dahalo, dat. - dative, det. - determined, dir. - directive, Dor. - Doric, du. - dual, E - East, Ebl. - Eblaite, Eng. - English, ep. - epigraphic, erg. - ergative, Est. Estonian, f. - feminine, Fal. - Faliscan, Fi. - Finnish, fin. - finalis, FU. - Fenno-Ugric, Ge. - Georgian, gen. genitive, Gl. - Gaulish, Gmc. - Germanic, Goid. - Goidelic, Gond. - Gondwan group, Goth. - Gothic, Gr. Greek, H. - Hadiyya, HD - hysterodynamic, Hebr. - Hebrew, heter. - heteroclitic, Hitt. - Hittite, Hom. Homeric, Hung. - Hungarian, id. - idem, II. - Indo-Iranian, inact. - inactive, indet. - indetermined, ins(tr). instrumental, Ir. - Irish, It. - Italic, Kh. - Khanty, Lat. - Latin, Latv. - Latvian, Laz. - Lazish, Lep. - Lepontic, Lesb. - Lesbian, Lith. - Lithuanian, loc. - locative, Luw. - Luwian, Lyd. - Lydian, Lyc. - Lycian, m. masculine, M - Middle, Ma. - Mansi, Marr. - Marrucine, Mars. - Marsian, Megr. - Megrelian, Messap. Messapic, Mord. - Mordvin, Myc. - Mycenaean, n. - neuter, N - North, nom. - nominative, O - Old, obl. oblique, OCS. - Old Church Slavonic, OHG. - Old High German, ON. - Old Nordic (incl. Old Icelandic), ORun. - Old Runic, Osc. - Oscan, Pael. - Paelignian, PD - proterodynamic, Phryg. - Phrygian, Pic. - Picenian, p- - proto-, pl. - plural, Pr(us). - Prussian, pred. - predicative, Q. - Qatabanian, S - South, Samoy. Samoyedic, sg. - singulár, Skt. - Sanskrit, Sl. - Slavic, soc. - sociative, suf. - suffix, Svan. - svanský, Sx. Saxon, Syr. - Syriac, term. - terminative, Toch. - Tocharian, tran. - transformative, Ugar. - Ugaritic, Ugr. Ugric, Umb. - Umbrian, Ved. - Vedic, Ven. - Venetic, voc. - vocative, Vol. - Volscan, W - West, Y - Young, Ye. - Yemsa, Yu. - Yudeo-.

\section{Literature}

ADAMS, Douglas Q. 1999. A Dictionary of Tocharian B. Amsterdam-Atlanta: Rodopi.

ANDRONOV, Mixail S. 1978. Sravnitel'naja grammatika dravidijskix jazykov. Moskva: Nauka.

ANTONSEN, Elmer. 1975. A Concise Grammar of the Older Runic Inscriptions. Tübingen: Niemeyer.

BEEKES, Robert S.P. 1985. The Origins of the Indo-European Nominal Inflection. Innsbruck: IBS 46.

BEEKES, Robert S.P. 1995. Comparative Indo-European Linguistics. An Introduction. Amsterdam - Philadelphia: Benjamins.

BLAŽEK, Václav. 1999. Numerals. Comparative-etymological analyses and their implications. Brno: Masarykova univerzita.

BLAŽEK, Václav. 2006. Traces of a common case system in Afroasiatic. In: Loquentes linguis. Linguistic and Oriental Studies in Honour of Fabrizio A. Pennacchietti, ed. by P.G. Borbone, A. Mengozzi, M. Tosco. Wiesbaden: Harrassowitz, 91-101.

BLAŽEK, Václav. 2010. Indoevropská substantivní deklinace [Indo-European declension of substantives]. Linguistica Brunensia 58, 2010/1-2, 51-91.

BLOCH, Jules. 1949. Préfixes et suffixes en Andaman. Bulletin de la Société de Linguistique de Paris 45, 1-46.

BrockelmanN, Carl. 1908. Grundriss der vergleichenden Grammatik der semitischen Sprachen, Bd. I: Laut- und Formenlehre. Berlin: Reuther \& Reichard. 
BRUGMANN, Karl. 1906/1911. Grundriss der vergleichenden Grammatik der indogermanischen Sprachen, II.1/2. Strassburg: Trübner.

CólerA, Carlos Jordán. 2005. Celtibérico. Zaragoza: Gorfisa.

COLLINDER, Björn. 1960. Comparative Grammar of the Uralic Languages. Stockholm: Almqvist \& Wiksell.

ČERMÁK, František. 1997. Jazyk a jazykověda. Praha: Pražská imaginace.

ČERNÝ, Václav A. 1975. Základy gruzínštiny. Praha: Academia.

DEŠERIEV, Ju. D. 1967. Čečenskij jazyk. In: Jazyki narodov SSSR: Iberijsko-kavkazskie jazyki. Moskva: Nauka, 190-209.

DEŠERIEV, Ju. D. 1967. Bacbijskij jazyk. In: Jazyki narodov SSSR: Iberijsko-kavkazskie jazyki. Moskva: Nauka, $228-245$.

DOLGOPOLSKY, Aron. 1991. Two problems of Semitic historical linguistics: I. Mimation and nunation; II. Akkadian reflexes of *s and *h. In: Semitic Studies in honor of Wolf Leslau on the occasion of his eighty-fifth birthday, Vol. I, ed. by Alan S. Kaye. Wiesbaden: Harrassowitz, 328-339.

DOLGOPOLSKY, Aron. 2005. Nostratic Grammar: Synthetic or Analytic? Orientalia et Classica. Trudy Instituta Vostočnyx kul'tur i antičnosti, vypusk VI: Aspekty komparativistiki 1. Moskva: Rossijskij Gosudarstvennyj Gumanitarnyj Universitet, 13-38.

EDAL = STAROSTIN, Sergei, Anna DYBO, Oleg MudRAK. 2003. Etymological Dictionary of the Altaic Languages. LeidenBoston: Brill.

ELIZARENKOVA, Tatjana Ja. 1987. Vedijskij jazyk. Moskva: Nauka.

ERHART, Adolf. 1982. Indoevropské jazyky. Srovnávací fonologie a morfologie. Praha: Academia.

ERHART, Adolf. 1993. Die indogermanische Nominalflexion und ihre Genese. Innsbruck: IBS 73.

EWAI = MAYRHOFER, Mannfred. 1986. Etymologisches Wörterbuch des Altindoarischen, I-III. Heidelberg: Winter.

FÄHNRICH, Heinz. 2007. Kartwelisches Etymologisches Wörterbuch. Leiden-Boston: Brill.

FISCHER, Wolfdietrich. 1972. Grammatik des klassischen Arabisch. Wiesbaden: Harrassowitz.

GAMKRelidze, Tamas V. \& IvAnOv, Vjačeslav V. (1984). Indoevropejskij jazyk i indoevropejcy. Tbilisi: Izdatel'stvo Tbilisskogo universiteta. In English: Indo-European and the Indo-Europeans: a reconstruction and historical analysis. Berlin: Mouton de Gruyter 1995.

GHL = A Grammar of Hittite Language, Part 1: Reference Grammar, by Harry A. Hoffner, jr. \& H. Craig MELCHERT. Winona Lake: Eisenbrauns 2008.

HAJdú, Péter. 1985. Ural’skie jazyki i narody, přeložil E. Xelimskij. Moskva: Progress.

HAJNAL, Ivo. 1995. Studien zum mykenischen Kasussystem. Berlin - New York: Walter de Gruyter.

HajNAL, Ivo. 2003. methodische Vorbemerkungen zu einer Palaeolinguistik des Balkanraums. In: Languages in Prehistoric Europe, ed. by Alfred Bammesberger \& Theo Vennemann. Heidelberg: Winter, 117-145.

HAMP, Eric P.. 1979. Indo-European ${ }^{*}{ }^{w}$ en- $H_{a}$. Zeitschrift für vergleichende Sprachforschung 93, 1-7.

HAMP, Eric P. 1981. Indo-European * $\left(H_{e}\right)$ op-. Münchener Studien zur Sprachwissenschaft 40, 39-60.

HAMP, Eric P. 1987. Varia. Études Celtiques 24, 185-189.

HAMP, Eric P. 1994. The Laryngeal Heteroclites. In: Indogermanica et Caucasica. Festschrift für K.H. Schmidt zum 65. Geburtstag, ed. Roland Bielmeier \& Reinhard Stempel. Berlin - New York: Walter de Gruyter, 35-40.

HAMP, Eric P. 1996. Varia II: 1. On the Old Irish dat. sg. in ${ }^{*}$ mi. Ériu 47, 209.

HAUDRY, Jean. 1982. Prehistoire de la flexion nominale indo-européenne. Lyon: Institut d'études indo-européennes de l'Université Jean Moulin (Lyon III).

HEG = Hittite Etymological Dictionary, by Jaan PUHVEL. Berlin - New York: Mouton de Gruyter 1984n.

HOFFMANN, Karl \& FORSSMAN, Bernhard. 1996. Avestische Laut- und Flexionslehre. Innsbruck: IBS 84.

HofírKOVÁ, Lucie \& BLAŽEK, Václav. 2012. Jmenná deklinace fino-sámských jazyků v ugrofinské perspektivě [Nominal Declension of the Fenno-Saamic Languages in the Fenno-Ugric Perspective]. Linguistica Brunensia 60, 127-146.

HŘEBÍČEK, Luděk. 1969. Turečtina. Praha: Academia.

ILLIČ-SvITYČ, Vladislav M. 1971-76-84. Opyt sravnenija nostratičeskix jazykov, I-III. Moskva: Nauka.

KLIMOV, Georgij A. 1962. Sklonenie v kartvel'skix jazykax v sravnitelno-istoričeskom aspekte. Moskva: AN SSSR.

KLINGENSCHMITT, Gerd. 1992. Die lateinische Nominalflexion. In: Latein und Indogermanisch. Akten des Kolloquiums der Indogermanischen Gesellschaft (Salzburg, Sept. 1986), ed. Oswald Panagl \& Thomas Krisch. Innsbruck: IBS 64, 89-135.

KLINGENSCHMITT, Gerd. 1994. Das Tocharische in indogermanischer Sicht. In: Tocharisch (Akten des Fachtagung der Indogermanischen Gesellschaft, berlin, sept 1990), ed. B. Schlerath. Reykjavík: TIES Suppl. Series, Vol. 4), 310411. 
KORTLANDT, Frederik. 1978. On the history of the genitive plural in Slavic, Baltic, Germanic, and Indo-European. Lingua 45, 281-300.

KORTLANDT, Frederik. 1984/2003. Proto-Armenian case endings. In: International symposium on Armenian linguistics. Erevan: Akademija nauk Armjanskoj SSR, 97-106 / Armeniaca. Ann Arbor: Caravan Books, 45-56.

KORTLANDT, Frederik. 2002. The Indo-Uralic Verb. In: Finno-Ugrians and Indo-Europeans: Linguistic and Literary Contacts. Proceedings of the Symposium at the University of Groningen (Nov. 2001). Maastricht: Shaker (Studia Fenno-Ugrica Groningana 2), 217-227.

KRAHE, Hans. 1948. Historische Laut- und Formenlehre. Heidelberg: Winter.

KRASUXIN, Konstantin G. 2004. Vvedenie v indoevropejskoe jazykoznanie. Moskva: Akademija.

KUČEROVÁ, Hana. 1962. Česko-finské rozhovory. Praha: SPN.

KULIKOV, Leonid. 2009. Evolution of Case Systems. In: Oxford Handbook of Case, ed. by Andrej Malchukov \& Andrew Spencer, 439-457.

LAMBERT, Pierre-Yves. 2001[1998-2000]. La tuile de Châteaubleau (Seine-et-Marne). Études celtiques 34, 57-115.

LEIA = Lexique étymologique de l'irlandais ancien, par Joseph VENDRYES \& Pierre-Yves LAMBERT. Dublin: Institute for Advanced Studies - Paris: CNRS Éditions 1959-96.

LejeunE, Michel. 1971. Lepontica. Études celtiques 12, 356-500.

LG = La langue gauloise, par Pierre-Yves LAMBERT. 2003. Paris: Errance.

LIPIŃSKI, Edward. 1997. Semitic Languages. Outline of a comparative Grammar. Leuven: Peeters (Orientalia Lovanensia Analecta 80).

MACDONELl, Arthur A. 1916[2000]. A Vedic Grammar for Students. Delhi: Motilal Banarsidass.

MACHEK, Václav. 1968. Etymologický slovník jazyka českého. Praha: Academia.

MAYRHOFER, Mannfred. 1986. Indogermanische Grammatik I.2.: Lautlehre [Segmentale Phonologie des Indogermanischen]. Heidelberg: Winter.

MAŽIULIS, Vytautas. 2004. Prūsu kalbos istorinè gramatika. Vilnius: Vilniaus universiteto leidykla.

Meriggi, Piero. 1980. Schizzo gramaticale dell'Anatolico. Roma: Atti della Accademia nazionale dei Lincei, Memorie: Classe di Scienze morali, storiche e filologiche, Serie VIII, Volume XXIV, Fasc. 3.

MLH = Monumenta Linguarum Hispanicarum IV: Die tartessischen, keltiberischen und lusitanischen Inschriften, von Dagmar WODTKO \& Jürgen UNTERMANN.

MLM = Monumenta Linguae Messapicae, I-II, Carlo de SIMONE \& Simona MARCHESINI. Wiesbaden: Reichert, 2002.

MoscATI, Sabatino et al. 1964. An Introduction to the Comparative Grammar of Semitic Languages. Wiesbaden: Harrassowitz.

NiKolaeV, Alexander. 2000. PIE ergativity and the Genitive in *osyo. In: Proceedings of the Eleventh Annual UCLA Indo-European Conference, ed. K. Jones-Bley, M.E. Huld \& A. Della Volpe. Washington D.C.: Institute for the Study of Man (Journal of Indo-European Studies Monograph Series No. 35), 293-309.

NIL = Nomina im indogermanischen Lexikon, von Dagmar S. WODTKo, Britta IRSLINGER \& Carolin SCHNEIDER. Heidelberg: Winter 2008.

Olsen, Birgit A. 1999. The Noun in Biblical Armenian. Origin and Word-Formation. Berlin-New York: Mouton de Gruyter.

OTRĘBSKI, Jan. 1956. Gramatyka języka litewskiego, Tom III: Nauka o formach. Warszawa: Państwowe wydawnictwo naukowe.

Pedersen, Holger. 1907. Neues und nachträgliches. KZ 40, 129-217.

Pedersen, Holger. 1926. La cinquième déclinaison latine. København: Høst \& Søn.

PINAULT, Georges-Jean. 1989. Introduction au tokharien. Paris: LALIES (Actes des sessions de linguistique et de littérature 7).

POKORNY, Julius. 1925. Altirische Grammatik. Berlin - Leipzig: Walter de Gruyter.

PORTMAN, M.V. 1887. A Manual of the Andamanese Languages. London: Allen.

RASMUSSEN, Jens E. 1987. Aspirated tenues and Indo-European phonation series. In: Acta Linguistica Hafniensia 20, 81-109.

RASMUSSEN, Jens E. 1989. Studien zur Morphophonemik der indogermanischen Grundsprache. Innsbruck: IBS 55.

RASMUSSEN, Jens E. 1999. Selected Papers on Indo-European Linguistics, I-II. Copenhagen: Museum Tusculanum University of Copenhagen.

RINGE, Don. 2006. From Proto-Indo-European to Proto-Germanic. Oxford: University Press. 
RIX, Helmut. 1976. Historische Grammatik des Griechischen. Laut- und Formenlehre. Darmstadt: Wissenschaftliche Buchgesellschaft.

RŮŽIČKA, Karel F. 1970. Úvod do swahilštiny. Praha: Academia.

SAVČENKO, Aleksej N. 1974. Sravnitel’naja grammatika indoevropejskix jazykov. Moskva: Vysšaja škola.

SCHINDLER, Jochem. 1975. L'apophonie des thèmes indo-européens en -r/n. Bulletin de la Société de Linguistique de Paris $70,1-10$.

Schmalstieg, William R. 1997. The Origin of the Neuter Nominative-Accusative Singular In *-OM. Journal of IndoEuropean Studies 25, 401-407.

SCHMITT, Rüdiger. 1981. Grammatik des Klassisch-Armenischen mit Sprachvergleichenden Erläuterungen. Innsbruck: IBS 32.

SIHLER, Andrew L. 1995. New Comparative Grammar of Greek and Latin. New York - Oxford: Oxford University Press.

SKALIČKA, Vladimír. 1945[2004] Über die Typologie der Bantusprachen. Citováno podle překladu Víta Dovalila: O typologii bantuských jazyků. In: Vladimír Skalička - Souborné dílo I, ed. František Čermák, Jan Čermák, Petr Čermák, Claudio Poeta. Praha: Karolinum, 284-315.

STREITBERG, Wilhelm. 1920. Gotisches Elementarbuch. Heidelberg: Winter.

SZEMERÉNYI, Oswald. 1985. Strukturelle Probleme der indogermanischen Flexion. Prinzipien und Modellfälle. In: Grammatische Kategorien. Funktion und Geschichte. Akten der VII. Fachtagung der Indogermanischen Gesellschaft (Berlin, Februar 1983), hrsg. Bernfried Schlerath \& V. Rittner. Wiesbaden: Reichert, 515-533.

SZEMERÉNYI, Oswald J.L. 1996. Introduction to Indo-European Linguistics. Oxford: Clarendon Press.

SzINNYEI, Josef. 1910. Finnisch-ugrische Sprachwissenschaft. Leipzig: Göschen.

THURNEYSEN, Rudolf. 1946. A Grammar of Old Irish. Dublin: Institute for Advanced Studies.

TICHY, Eva. 2004. Indogermanistisches Grundwissen für Studierende sprachwissenschaftlicher Disziplinen ${ }_{2}$. Bremen: Hempen (1st edition 1999).

Tremblay, Xavier. 2004. Die Ablautstufe des Lokativs der akrostatistischen Nomina. In: Per Aspera ad Asteriscos. Studia Indogermanica in honorem Jens E. Rasmussen, ed. by Adam Hyllested et al. Innsbruck: IBS 112, $573-590$.

UB = URBANOVÁ, Daniela \& BLAŽEK, Václav. 2008. Národy starověké Itále, jejich jazyky a písma. Brno: Host.

VAVROUŠEK, Petr. 2008. Rekonstrukce? Rekonstrukce! Praha: Ústav srovnávací jazykovědy Filozofické fakulty Univerzity Karlovy.

de VAAN, Michiel. 2008. Etymological Dictionary of Latin and the other Italic Languages. Leiden-Boston: Brill.

WAtKINS, Calvert. 1997. Luvo-Hittite :lapan(a)-. In: Studies in Honor of Jaan Puhvel, Part I, ed. D. Disterheft et al. Washington D.C., 29-35.

ZvelebIL, Kamil V. 1990. Dravidian Linguistics. An Introduction. Pondicherry: Institute of Linguistics and Culture.

В. БЛАЖЕК. Индоевропейское именное склонение в ностратической перспективе.

В статье обобщены текущие представления об истории и происхождении системы именного склонения в индоевропейских языках, а также вкратце сравниваются несколько гипотез о причинах возникновения т. н. «тематического» склонения. Реконструированная парадигматическая система далее сравнивается с соответствующими системами, восстановленными для других ветвей гипотетической ностратической макросемьи - семитской (и, шире, афроазиатской), картвельской, уральской. Автор заключает, что, поскольку большинство падежных окончаний праиндоевропейского языка этимологизируются либо на основе самостоятельных индоевропейских лексем, либо на внешнем уровне (при сравнении с другими ностратическими языками), это можно расценивать как серьезный аргумент в пользу аналитического характера праностратического языка.

Ключевые слова: Историческое языкознание, индоевропейские языки, сравнительная морфология, ностратическая гипотеза. 